\title{
Carbonate shelf development and early Paleozoic benthic diversity in Baltica: a hierarchical diversity partitioning approach using brachiopod data
}

\author{
Amelia M. Penny* (D), Olle Hints, and Björn Kröger (D)
}

\begin{abstract}
The Ordovician-Silurian ( 485-419 Ma) was a time of considerable evolutionary upheaval, encompassing both great evolutionary diversification and one of the first major mass extinctions. The Ordovician diversification coincided with global climatic cooling and paleocontinental collision, the ecological impacts of which were mediated by region-specific processes including substrate changes, biotic invasions, and tectonic movements. From the Sandbian-Katian ( $453 \mathrm{Ma}$ ) onward, an extensive carbonate shelf developed in the eastern Baltic paleobasin in response to a tectonic shift to tropical latitudes and an increase in the abundance of calcareous macroorganisms. We quantify the contributions of environmental differentiation and temporal turnover to regional diversity through the Ordovician and Silurian, using brachiopod occurrences from the more shallow-water facies belts of the eastern Baltic paleobasin, an epicontinental sea on the Baltica paleocontinent. The results are consistent with carbonate shelf development as a driver of Ordovician regional diversification, both by enhancing broadscale differentiation between shallow- and deep-marine environments and by generating heterogeneous carbonate environments that allowed increasing numbers of brachiopod genera to coexist. However, temporal turnover also contributed significantly to apparent regional diversity, particularly in the Middle-Late Ordovician.
\end{abstract}

Amelia M. Penny ${ }^{\dagger}$ and Björn Kröger. Finnish Museum of Natural History, University of Helsinki, Jyrängöntie 2, 00560 Helsinki, Finland. E-mail: bjorn.kroger@helsinki.fi. 'Present address: Centre for Biological Diversity, School of Biology, University of St. Andrews, St. Andrews, Fife KY16 9TF, United Kingdom. E-mail: amp29@standrews.ac.uk

Olle Hints. Department of Geology, School of Science, Tallinn University of Technology, Ehitajate tee 5, 19086 Tallinn, Estonia.E-mail: olle.hints@taltech.ee

Accepted: 18 January 2021

*Corresponding author.

\section{Introduction}

The Ordovician and Silurian were intervals of tremendous evolutionary and environmental upheaval, encompassing both the great Ordovician biodiversification event (GOBE), and the onset and aftermath of the Late Ordovician mass extinction (LOME) (Webby et al. 2004; Servais and Harper 2018; Rasmussen et al. 2019; Stigall et al. 2019). This has inspired intensive study of Ordovician-Silurian diversity patterns, because of their potential to reveal the mechanisms underlying extinction and diversification (e.g., Sepkoski 1988; Miller and Connolly 2001; Webby et al. 2004; Servais et al. 2010; Hautmann 2014; Penny and Kröger 2019).

The GOBE had multiple global environmental drivers that were mediated by regional-scale processes, including carbonate platform development, biotic invasions, and latitudinal shifts due to tectonic movements (e.g., Kiessling et al. 2003; Servais and Harper 2018; Stigall 2018). The impact of these regional processes on diversity is exemplified by the eastern Baltic paleobasin. Over the Ordovician, Baltica experienced regional warming as it drifted from temperate to equatorial latitudes, accompanied by the development of an extensive, reef-bearing carbonate shelf (Dronov and Rozhnov 2007;

(C) The Author(s), 2021. Published by Cambridge University Press on behalf of The Paleontological Society. This is an Open Access article, distributed under the terms of the Creative Commons Attribution licence (http://creativecommons.org/ licenses/by/4.0/), which permits unrestricted re-use, distribution, and reproduction in any medium, provided the original work is properly cited. 
Kröger et al. 2017b). Baltoscandia also has an abundant, well-preserved Ordovician-Silurian fossil record combined with a well-characterized stratigraphy (e.g., Paškevičius 1997; Raukas and Teedumäe 1997; Ebbestad et al. 2007; Calner et al. 2013; Bauert et al. 2014). This makes it an excellent focus for investigating how the environmental heterogeneity associated with carbonate shelf development influenced regional diversity patterns through the GOBE and LOME, as well as the impact of temporal turnover on these patterns.

Early Paleozoic Baltoscandian richness curves are available for several clades (e.g., Hammer 2003; Kaljo et al. 2011), but we follow other workers (e.g., Hints and Harper 2003; Rasmussen et al. 2007, 2009; Lam and Stigall 2015; Hints et al. 2018) in focusing on brachiopods. The taxonomy and biostratigraphy of Baltoscandian brachiopods have been studied by generations of specialists, such as Armin Öpik, Tatjana N. Alikhova, Arvo Rõõmusoks, Madis Rubel, Linda Hints, and Petras Musteikis (for recent reviews, see Harper et al. 2015; Harper and Hints 2016). Because they are a major component of the early Paleozoic benthos, brachiopods are also a good model clade for investigating the impact of substrate changes on benthic diversity.

Here, we quantify how temporal turnover and environmental heterogeneity contributed to brachiopod diversification in the eastern part of the Baltic paleobasin during the GOBE and also to the recovery after the LOME.

\section{Geologic and Depositional Setting}

During the early Paleozoic, the Baltic paleobasin was an extensive epicontinental sea of the Baltica paleocontinent. The extent and development of the Baltic paleobasin was closely related to the Baltic Syneclise, a tectonic structure with a roughly $700-\mathrm{km}$-long southwest-northeast oriented long axis (Tuuling 2019) (Fig. 1). During the Cambrian-Silurian, Baltica underwent a plate-tectonic shift from temperate to equatorial latitudes (Torsvik and Cocks 2016), with a corresponding shift in regional sediment deposition from cool-water glauconitic carbonates and siliciclastics to reduced siliciclastic input and tropical

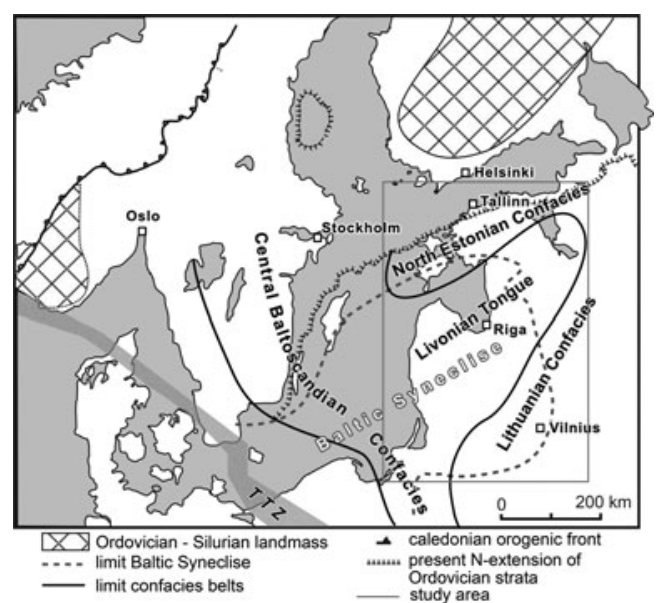

FIGURE 1. Regional facies map, showing confacies belts of the Baltic paleobasin and the extent of the Baltic Syneclise. TTZ, Teisseyre-Tornquist Zone. Compiled from Jaanusson (1976), Lazauskiene et al. (2003), and Tuuling (2019). The study region is outlined with a gray square.

carbonates (Torsvik et al. 1996; Cocks and Torsvik 2005; Dronov and Rozhnov 2007) (Fig. 2).

During the Middle and Late Ordovician, the Baltic paleobasin differentiated into shelf and basin facies zones (Fig. 3). Jaanusson (1976) distinguished a series of depositional zones, among others the Livonian Basin in the easternmost center of the basin and the North Estonian and Lithuanian Confacies belts as horseshoelike marginal zones (Fig. 1). The most distal of these is the Scanian Confacies belt in the extreme southwest of the basin comprising parts of modern Denmark and Poland, which is dominated by graptolitic shales.

The spatiotemporal development of the Baltic paleobasin is divided into five stages that are distinct with respect to tectonic subsidence rate, climate, large-scale eustatic sea-level trend, and differences in relative influx and production of siliciclastics and carbonates (Einasto and Nestor 1973; Nestor and Einasto 1977, 1997; Einasto 1986). The first two stages, the (1) transgression and (2) unification stages, are equivalent to a ramp situation, with a gently dipping seafloor slope, relatively low spatial facies differentiation, and very slow depositional rates. The last three stages, the (3) differentiation, (4) stabilization, and (5) infilling stages, correspond to a carbonate platform situation with high carbonate depositional rates, 

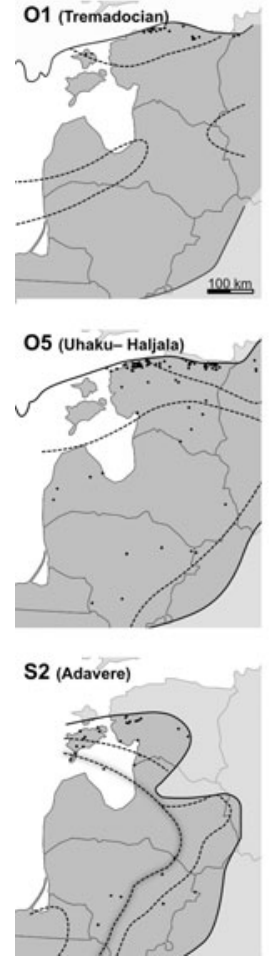
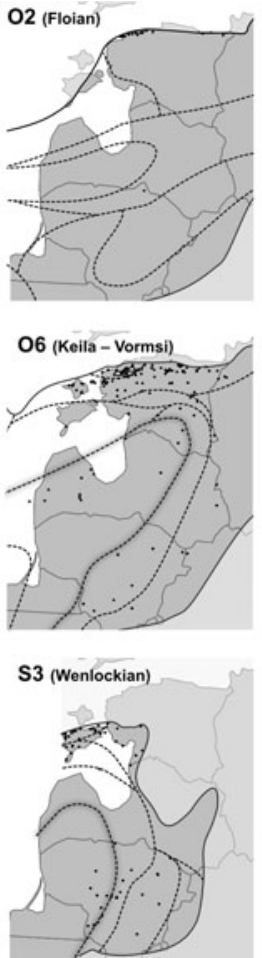
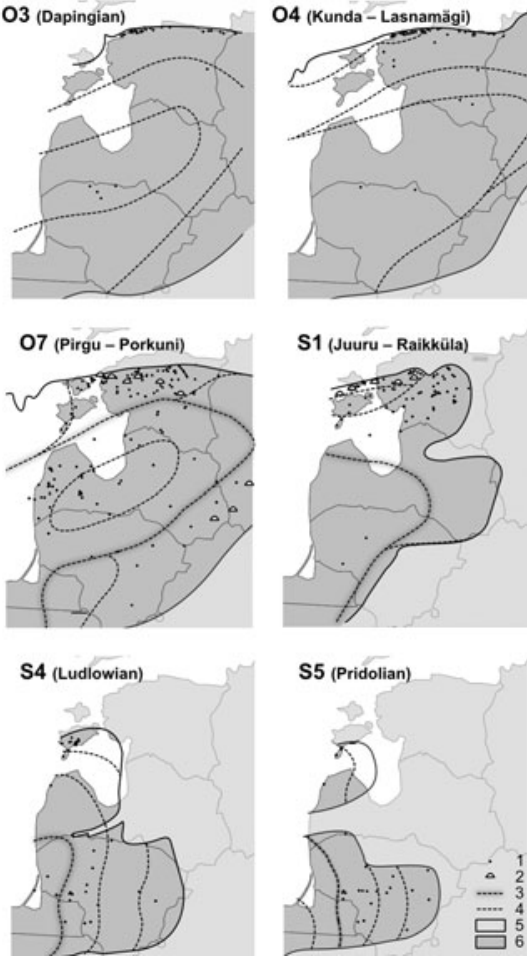

FIGURE 2. Overview of brachiopod localities with lithologic information used in this study. Maps show extent of outcrop and subcrop of strata of the respective time bins. Hatched lines show facies boundaries. Maps are adopted from Paškevičius (1997: O1, Tremadoc, fig. 41; O2, Latorp, fig. 42; O4, Kunda, fig. 43; O5, Kukruse, fig. 44; O6, Oandu, fig. 45; O7, Ashgill, fig. 47; S1, Raikküla, fig. 59; S2, Adavere, fig. 60; S4, Ludlow, fig. 62; S5, Pridoli, fig. 63) and Raukas and Teedumäe (1997: O3, Volkhov, fig. 142). 1, brachiopod locality with lithologic information; 2 , reef occurrence; 3 , boundary between our "basinal," "platform" areas; 4, facies boundary; 5, no time-bin sediments preserved; 6, extent of time-bin sediments.

high spatial bathymetric differentiation, phases of aggregation and progradation, and eventual termination. The change between the ramp and the platform situation was relatively abrupt and occurred at around the Sandbian/Katian stage boundary during the regional KeilaOandu stages (see also Hints et al. 1989; Nestor and Einasto 1997).

The late Sandbian-early Katian change from ramp to platform depositional settings coincided with a drastic inversion in wind and water currents (Kiipli et al. 2007) and a turnover in the biota (Ainsaar et al. 2004). This occurred alongside the first widespread development of reefs (Kröger et al. 2016) and the development of an algal-rich micritic limestone facies (Kröger et al. 2020). The massive increase in carbonate production was probably the main cause for the establishment of a stable, widespread, flattopped carbonate platform and the consequent development of an extensive Ordovician-Silurian facies mosaic (in the sense of Wright and Burgess 2005). The different carbonate platform substrates include: extensive hardground development (Orviku 1940; Saadre 1993; Dronov et al. 2000; Vinn and Wilson 2010), shallow and lagoonal soft sediments (e.g., Einasto 1986; Teller 1997), a micritic limestone with abundant calcareous algae (Spjeldnæs and Nitecki 1994; Kröger et al. 2020), kilometer-wide shoal deposits of echinoderm grainstone, and reefs and mud-mounds (e.g., Aaloe and Nestor 1977; Tuuling and Flodén 2013; Kröger et al. 2014, 2016; Kaminskas et al. 2015).

Hirnantian diamictites exposed in Poland demonstrate that icebergs reached the western margin of Baltica, despite its position at subtropical latitudes (Porębski et al. 2019). Carbonate deposition continued through the Hirnantian and into the Silurian, with ongoing 


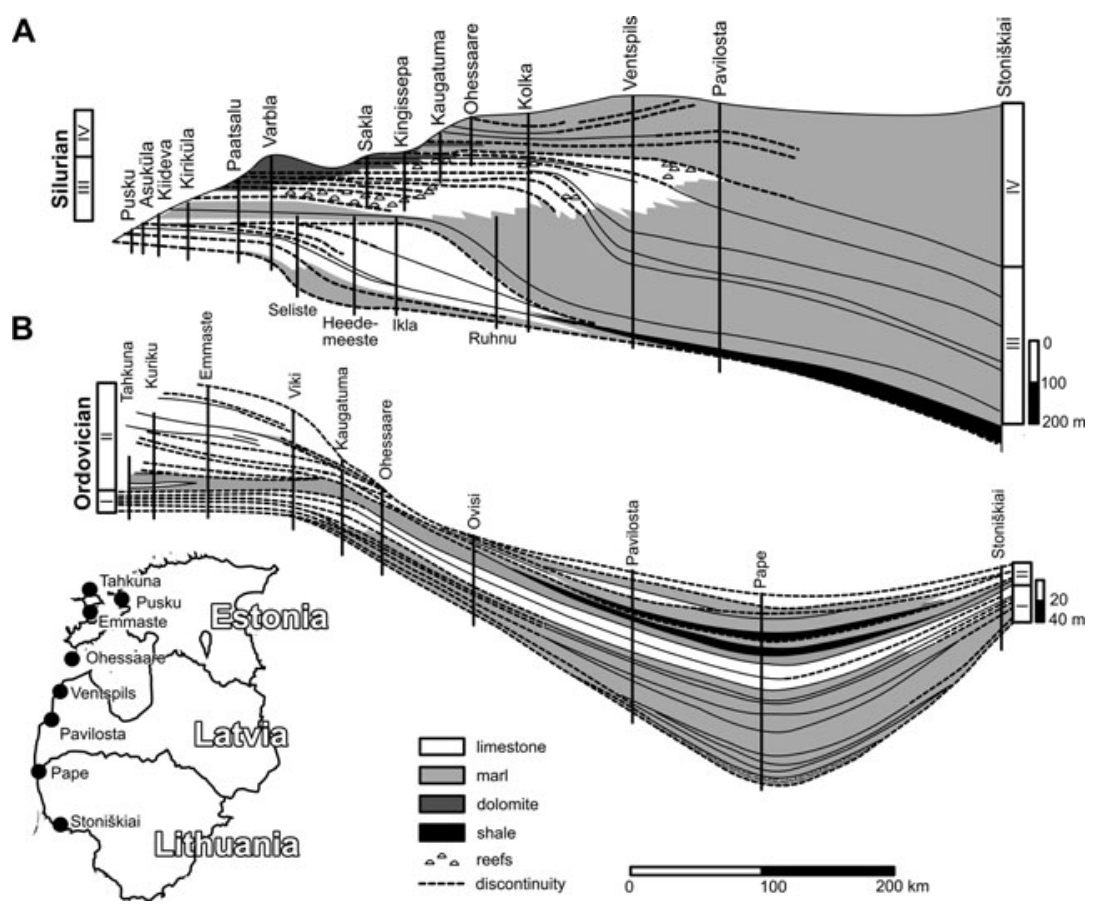

FIGURE 3. North-south cross sections showing facies distribution through the northern flank of the Baltic Basin from western Estonia in the north to western Lithuania in the south. Vertical lines mark locations of drill-core sections and the distributions of different lithologies. A, Silurian strata; based on Nestor and Einasto (1982). B, Ordovician strata; based on Dronov et al. (2011). Roman numerals identify depositional intervals sensu Nestor and Einasto (1997).

high levels of facies differentiation between shallow-marine carbonate-rich and distal siliciclastic settings (Kiipli et al. 2004).

\section{Methods}

Data, Downloads, and Data Cleaning.-We used combined brachiopod fossil occurrence data from the literature-based Paleobiology Database (PBDB, https://paleobiodb.org) and from the specimen-level database of the Geoscience Collections of Estonia (SARV, https:// geocollections.info; Hints et al. 2019), comprising a dataset of more than 13,000 occurrences from more than 800 localities in the eastern Baltic paleobasin (Estonia, Latvia, and Lithuania) (downloaded 13 January 2020). Brachiopod occurrences from the combined databases are mapped in Figure 2. Because the PBDB and SARV databases use different "collection" concepts, we assigned all occurrences to artificial collections, wherein a "collection" comprises all brachiopod occurrences within a lithostratigraphic unit at a single location, with location coordinates matched at a precision of three decimal places.

Lithologic and stratigraphic data were obtained from data associated with the PBDB and SARV occurrences, from a separate download of drill-core data compiled within the SARV, and from our own compilation from the literature. Only brachiopod occurrences identified to genus or species level were used for the analysis. Lithostratigraphic units of formation, member, and bed level were used. The hierarchy of the lithostratigraphic units, and in some cases their names, changed over the historical course of stratigraphic research. We corrected manually for historical name changes. Because we aimed to get a proxy for spatial and temporal lithologic heterogeneity, we flattened the hierarchy of lithologic names and considered each name as reflecting a distinct lithostratigraphic unit with equal value. Sequence boundaries were taken from Nielsen (2004), Johnson (2006), and Dronov et al. (2011). 


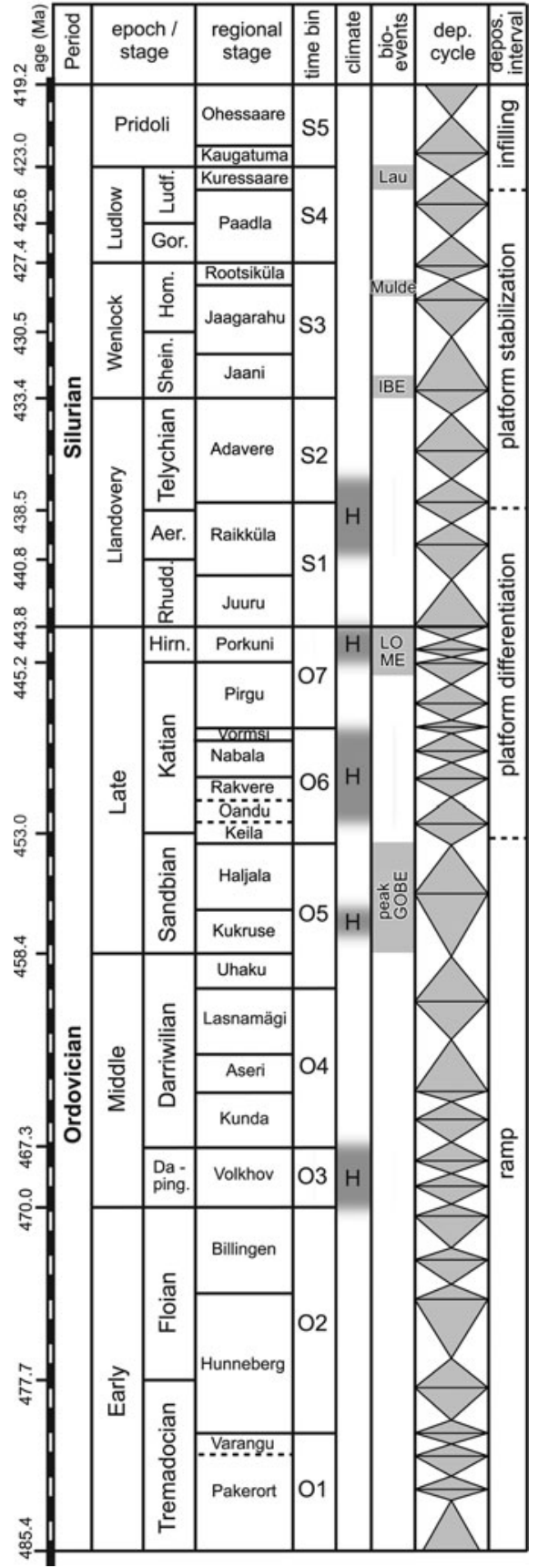

FIGURE 4. Stratigraphic scheme showing time binning, depositional cycles, and stages of the depositional model for the Baltic paleobasin. Compiled from Gradstein et al. (2012), Männik (2014), and Lindskog et al. (2017) for absolute time; Kiipli et al. (2016, 2017) for climate; Calner (2008) and Rasmussen et al. (2019) for bio-events; Nielsen (2004), Johnson (2006), and Dronov et al. (2011) for depositional cycles; Nestor and Einasto (1997) for depositional intervals. H, humid interval. Stage abbreviations: Daping., Dapingian; Hirn., Hirnantian; Rhudd., Rhuddaninan; Aer., Aeronian; Shein., Sheinwoodian; Hom., Homerian; Gor., Gorstian; Ludf., Ludfordian.
Time Bins.-The Ordovician and Silurian strata of the eastern Baltic paleobasin were divided into 12 time bins with an average duration of 5.6 Myr (Fig. 4). The shortest time bin is S5 (3.8 Myr) and the longest is $\mathrm{O} 4(8.3 \mathrm{Myr})$. Time binning was based on well-resolved stratigraphic horizons and reflects a compromise between time resolution and available data. Absolute ages of time-bin boundaries were taken from Gradstein et al. (2012) and Lindskog et al. (2017).

The Silurian record of the eastern Baltic paleobasin is included for several reasons. By including more time bins, we could track the relationships between regional diversity and substrate change from the initiation of the carbonate shelf in the Baltic paleobasin to the eventual infilling of the paleobasin in the late Silurian-Early Devonian. This encompasses more change in substrates and biodiversity and also provides points of comparison for the Ordovician data, allowing evaluation of the influence of time-specific biodiversity change and regional spatial and facies effects.

Identifying Biogenic Lithologies. - We classified lithostratigraphic units into either (1) biodominated lithologies comprising carbonates of primarily organismic origin; and (2) non-biodominated lithologies comprising predominantly siliciclastic sediments and chemical sedimentary rocks. In the first category are all limestone lithologies, including marly, argillaceous, silty, dolomitic, and glauconitic limestone. In the second category are shale, marl, siltstone, sandstone, glauconite, dolomite, and gypsum lithologies. For simplicity, we call the biodominated category "carbonate-dominated" and the non-bio-dominated category "siliciclastic-dominated," although dolomites are also carbonates, and gypsum is not siliciclastic. We include a list of lithostratigraphic units and their designations as carbonate and siliciclastic dominated in Supplementary Material 1. Time bin S2 was excluded from some analyses, because the only carbonate-dominated lithostratigraphic unit it contains is the Rumba Formation, which contains a very low diversity assemblage dominated by a single genus, which sometimes causes the mean diversity to decline at higher hierarchical levels (see "Diversity Partitioning" section for details of the hierarchical partitions). 
Diversity Partitioning.-We use the term "richness" to refer to the number of genera (which may be a raw count or an estimate based on some form of standardization) and "diversity" as an umbrella term when referring to diversity measures in the Hill number family. These include richness, but also the Shannon and Simpson diversities, which are the Shannon and Simpson indices converted to their corresponding Hill numbers (terminology after Hsieh et al. 2016). "Alpha diversity" refers to diversity within hierarchically partitioned categories, "beta diversity" refers to diversity difference between categories, and "gamma diversity" refers to the regional diversity; each may be measured with any of the three diversity measures used in this study. Where we refer to alpha, beta, or gamma diversity in only one of the diversity measures, we use the Greek letter with a subscript (e.g., $\gamma_{S}$ is regional diversity, measured with richness; $\gamma_{\text {shan }}$ and $\gamma_{\text {sim }}$ would give the corresponding Shannon and Simpson diversities, respectively). All analyses were performed at the genus level.

Total (gamma) diversity can be partitioned into alpha and beta diversity using either additive or multiplicative approaches. While alpha and gamma diversity have the same meanings in both additive and multiplicative diversity partitioning, they differ in their concepts of beta diversity (which is also calculated using a range of other methods; reviewed in Koleff et al. 2003). In multiplicative diversity partitioning, beta diversity is the ratio of gamma diversity to alpha diversity (Koleff et al. 2003; Whittaker 1972), while in additive diversity partitioning, beta diversity is gamma diversity minus alpha diversity (Lande 1996).

Both diversity partitioning approaches can be used in hierarchical sampling schemes, which assign samples to progressively larger nested groups to assess how much diversity is contributed at each level. Hierarchical partitioning is readily applicable to fossil assemblages, because hierarchical sampling mirrors the hierarchical nature of lithostratigraphic and chronologic units (Patzkowsky and Holland 2012). In hierarchical additive partitioning, beta diversity is the difference between the pooled diversity of a group of samples at a given hierarchical level and the mean alpha diversity of the samples that have been pooled (Lande 1996). In hierarchical multiplicative diversity partitioning, beta diversity is the pooled diversity at a given hierarchical level divided by the mean diversity of its component samples (Jost et al. 2010).

Additive diversity partitioning is sometimes preferred over multiplicative diversity partitioning, because it yields beta-diversity values in the same units as alpha and gamma diversity (e.g., Patzkowsky and Holland 2007; Holland 2010). Holland (2010) also advocated using three indices of diversity in parallel-richness, the Shannon index (also called the Shannon entropy), and the Simpson index (also called the Gini-Simpson index) — to evaluate diversity patterns in common and rare taxa and to control for the fact that richness is highly sensitive to sample size (Magurran 2004). Richness, being a simple count of the taxa in an assemblage, gives equal weight to all taxa, and consequently may be strongly influenced by the rarest taxa in an assemblage, as most of the species in a community tend to occur at low abundance (Whittaker 1970; Reddin et al. 2015). The Simpson index is most strongly influenced by the commonest taxa in an assemblage, which are arguably the most ecologically important (Gaston 2010), while the Shannon index has an intermediate sensitivity (for a full explanation, see Jost 2007; Jost et al. 2010).

However, the Shannon and Simpson indices do not behave additively and can give misleading results (Jost et al. 2010). The solution, proposed by Jost et al. (2010), is to convert each index to its corresponding Hill number (Hill 1973), also called its "effective number of species," which is the number of species corresponding to the given diversity index when the species abundance distribution is perfectly even. These values can easily be compared with richness, because their units are the same.

After conversion to Hill numbers, the Shannon and Simpson indices yield the same within-group diversities whether partitioned multiplicatively or additively (Ricotta 2005; Jost et al. 2010). In this study, we used hierarchical multiplicative diversity partitioning with Hill numbers, because it yields the same within-category diversities as additive diversity partitioning and is easier to implement 
using the $\mathrm{R}$ package vegan (Oksanen et al. 2018). However, in places we have expressed the differences in mean alpha diversity between hierarchical levels as a percentage of gamma diversity; this is not strictly equivalent to hierarchical additive diversity partitioning, but we use it as an additional, intuitive indicator of faunal difference between sampling units.

We used the function multipart, within the $\mathrm{R}$ package vegan (Oksanen et al. 2018), to perform multiplicative diversity partitioning using the Tsallis entropy, with scale factors 0 , 1 , and 2 corresponding to taxonomic richness, Shannon index, and Simpson index. The resulting alpha and gamma diversities are given as their corresponding Hill numbers; we refer to these as the richness, Shannon diversity, and Simpson diversity, following Hsieh et al. (2016).

Data from 177 lithostratigraphic units were analyzed, of which 38 contain only a single collection. To avoid discarding these lithostratigraphic units, we present the raw data for all lithostratigraphic units containing five occurrences or more. We include coveragestandardized results, which show a substantially similar pattern, in Supplementary Material 2. Coverage was measured using Good's $u$ (Good 1953), using a method from Alroy (2014) as implemented by Brocklehurst et al. (2018). We coverage-standardized each lithostratigraphic unit to a Good's $u$ of 0.5 , a value chosen to maximize the number of time bins that would run. Lithostratigraphic units with lower coverage were discarded, and those whose coverage was higher were subsampled until the standardization coverage was reached. Subsampling was repeated 100 times for each time bin, and the mean diversities and associated $p$-values from null modeling recorded. Increasing the number of subsampling runs had a minimal effect on the results. We used the null modeling function in multipart to perform individual-based randomization, which randomly assigns occurrences to samples at the lowest level of the hierarchy and assesses whether the diversities in the sample are significantly different from those of the randomized data. Null models were run with 99 iterations for each subsampling run, and when reporting results, we focus our discussion on alpha and beta diversities with mean $p$-values $<0.1$.

We used environmental partitioning to evaluate how faunal differences between lithologies contributed to regional diversity patterns, which relates to the influence of environmental preference and substrate heterogeneity on assemblage heterogeneity. The basic sample for alpha-diversity calculation was the lithostratigraphic unit, approximately equivalent to a formation. Formations have been taken to represent metacommunities, and hence may be ecologically meaningful units (Hofmann et al. 2019). We used a three-level hierarchy, with lithostratigraphic units nested within carbonate-dominated or siliciclastic-dominated lithologies, with the highest hierarchical level being the whole study region. We also evaluated beta diversity within siliciclastic- and carbonate-dominated lithologies by performing separate two-level partitions of siliciclasticand carbonate-hosted diversity. Where we suspected that time binning might be affecting the diversity curves produced, we performed secondary analyses at stage-level temporal resolution.

For temporal diversity partitioning, we used a three-level hierarchy to evaluate how faunal turnover between stages contributed to the diversity curve. Again, we used lithostratigraphic units as the basic units for alphadiversity calculation, followed by within-stage and within-time bin diversity. Brachiopod occurrences lacking stage level temporal resolution were excluded from this analysis.

We also performed diversity partitioning within shelf and basin facies. Brachiopod occurrences were assigned to shelf or basin facies based on their geographic locations; the $R$ package icosa (Kocsis 2017) was used to generate hexagonal equal-area grids of $\sim 37 \mathrm{~km}$ per side, and occurrences were assigned to grids using the locate() function. The resulting grids were used as the sampling unit and were overlain on a facies map of the Baltic region to assign them to the shelf or basin facies for analysis. Comparison of shelf and basin diversity patterns covers the time interval from bin $\mathrm{O} 6$ onward, as this is when the platform differentiation phase began (Fig. 4).

The meanings of different diversities within the partitioning schemes are summarized in 
TABLE 1. Meanings of different diversity terms used in the hierarchical partitions.

\begin{tabular}{|c|c|c|c|c|c|}
\hline & Alpha $1(\alpha 1)$ & Beta $1(\beta 1)$ & Alpha $2(\alpha 2)$ & Beta $2(\beta 2)$ & Gamma $(\gamma)$ \\
\hline $\begin{array}{l}\text { Temporal } \\
\text { partitions }\end{array}$ & $\begin{array}{l}\text { Mean diversity } \\
\text { within } \\
\text { lithostratigraphic } \\
\text { units }\end{array}$ & $\begin{array}{l}\text { The mean value of alpha 2/ } \\
\text { mean alpha, across all } \\
\text { stages in a time bin. } \\
\text { Reflects faunal difference } \\
\text { between lithostratigraphic } \\
\text { units within stages. }\end{array}$ & $\begin{array}{l}\text { Mean } \\
\text { diversity } \\
\text { within } \\
\text { stages in a } \\
\text { time bin }\end{array}$ & $\begin{array}{l}\text { Gamma/mean } \\
\text { alpha } 2 \text {. Reflects } \\
\text { faunal difference } \\
\text { between stages } \\
\text { in a time bin. }\end{array}$ & $\begin{array}{l}\text { Regional } \\
\text { diversity } \\
\text { within a } \\
\text { time bin }\end{array}$ \\
\hline $\begin{array}{l}\text { Lithologic/ } \\
\text { environmental } \\
\text { partitions }\end{array}$ & As above & $\begin{array}{l}\text { The mean value of alpha2/ } \\
\text { mean alpha, across both } \\
\text { lithological categories. } \\
\text { Reflects faunal difference } \\
\text { between lithostratigraphic } \\
\text { units within lithological } \\
\text { categories. }\end{array}$ & $\begin{array}{l}\text { Mean } \\
\text { diversity } \\
\text { within } \\
\text { lithologic } \\
\text { categories in } \\
\text { a time bin }\end{array}$ & $\begin{array}{l}\text { Gamma/mean } \\
\text { alpha } 2 \text {. Reflects } \\
\text { faunal difference } \\
\text { between } \\
\text { lithological } \\
\text { categories in a } \\
\text { time bin. }\end{array}$ & As above \\
\hline
\end{tabular}

Table 1. Alpha, beta, and gamma diversity are referred to by their Greek characters, with subscripts denoting richness, Shannon diversity, or Simpson diversity.

Independent Gamma-Diversity Estimates.-In the hierarchical diversity partitioning analyses, coverage may vary between time bins. To estimate the richness trajectory through time, we used independently calculated richness curves produced using two methods. First, we used the estimate $D$ function in the $\mathrm{R}$ package iNEXT (Hsieh et al. 2016), standardizing to a coverage of 0.7 , which is the maximum coverage at which time bins O3-S5 will run. Second, we used the capture-recapture (CR) modeling approach (Nichols and Pollock 1983; Liow and Nichols 2010) by fitting the Jolly-Seber model following the POPAN formulation (Schwarz and Arnason 1996; see also Kröger et al. [2019] for details of the method). We also produced coverage-standardized and $\mathrm{CR}$ modeling approach richness curves at stage-level temporal resolution to visualize how the time binning might influence richness trajectories, excluding stages without occurrences or where the estimateD function suggested large prediction bias. Because different methods can be expected to produce different richness estimates, we focus our discussion on trends in the data rather than absolute values. To determine whether carbonate-dominated and siliciclastic-dominated lithologies showed the same diversity patterns, we calculated independent coveragestandardized richness curves for each lithologic category.
Occupancy as an Abundance Proxy.-In our study, direct brachiopod abundance data were not available. We therefore use the number of localities with occurrences as a rough proxy of abundance with the a priori assumptions that detection in the fossil record is, at least in part, dependent on abundance and that more-abundant species have higher occupancies (see e.g., Gaston et al. 2000).

\section{Results}

Regional Richness $\left(\gamma_{S}\right)$ over the OrdovicianSilurian.-The GOBE and LOME are expressed in the regional richness patterns derived from CR (Fig. 5). With stage-level resolution, $\gamma_{S}$ increases in two pulses, one in the Floianearly Dapingian (Billingen-Kunda regional stages), with a second, larger pulse in the Sandbian. The $\gamma_{S}$ decline during time bin $\mathrm{O} 7$ is an effect of the time-binning strategy used, and with stage-level resolution, $\gamma_{S}$ continues to increase up until the Porkuni (Fig. 5) and then abruptly declines into the Silurian, with only a limited recovery. The LOME is not preceded by a diversity loss and instead represents a relatively abrupt diversity decline between the Porkuni and Juuru regional stages.

Temporal Taxonomic Turnover.-Taxonomic turnover between regional stages, $\beta 2$ in our temporal partitioning scheme, is a major contributor to within-bin diversity, though its impact is highly dependent on the length of time bins and the diversity index used (Fig. 6). The Sandbian-Katian (time bin O6) is particularly strongly influenced by this effect 


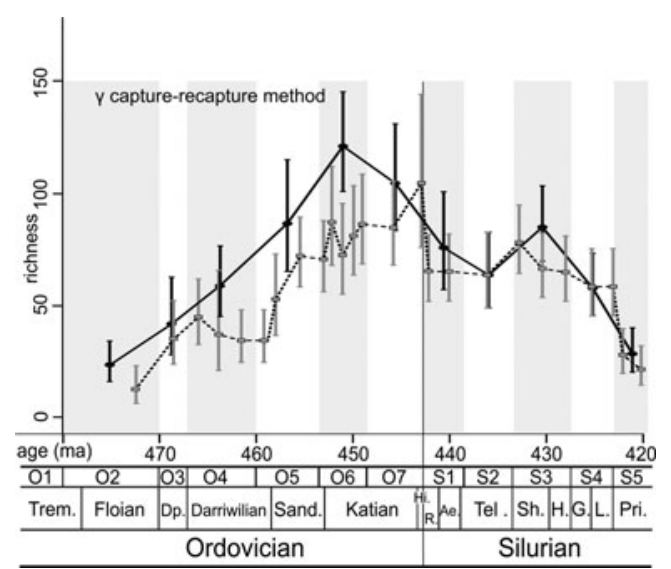

FIGURE 5. Regional gamma-diversity curve based on CR modeling at time-bin and stage temporal resolution. Black ovals and solid line, gamma diversity at time-bin resolution; gray rectangles and dotted line, gamma diversity at stage resolution. Use of longer time bins masks the two pulses of regional diversification visible at the stage level and also shifts the apparent regional diversity peak to the Katian (O6 bin), whereas with stage-level temporal resolution, the peak is in the Porkuni stage (Hirnantian; O7 bin). Stage abbreviations are: Dp., Dapingian; Sand., Sandbian; Hi, Hirnantian; R., Rhuddanian; Ae., Aeronian; Tel., Telychian; Sh., Sheinwoodian; H., Homerian; G., Gorstian; L., Ludfordian; Pri., Pridoli.

(Fig. 6B,C), though it is reduced when using the Shannon and Simpson diversities (Table 2).

Environment-Specific Diversity Trajectories.As the Estonian and Lithuanian shelves developed, they created broadscale substrate heterogeneity in the eastern Baltic paleobasin, and differentiation between shallow-water and deep-marine facies. Shelfal localities typically have higher richness than basinal ones, and platform and basin facies also show distinct richness trends (Fig. 7).

Differences in richness trajectories between shelf and basin are also reflected in differences in the diversity trajectories of carbonate- and siliciclastic-dominated lithologic categories, as carbonate-dominated lithologies predominantly occur on the shelf, at least after the Early Ordovician (Fig. 3). Independent richness curves for carbonate- and siliciclastic-dominated lithologies (Fig. 8) indicate that in the Ordovician, carbonate lithologies typically hosted higher richness than siliciclastic ones. However, parallel increases in carbonate- and siliciclastic-hosted richness over the Ordovician may suggest diversification drivers that operated across

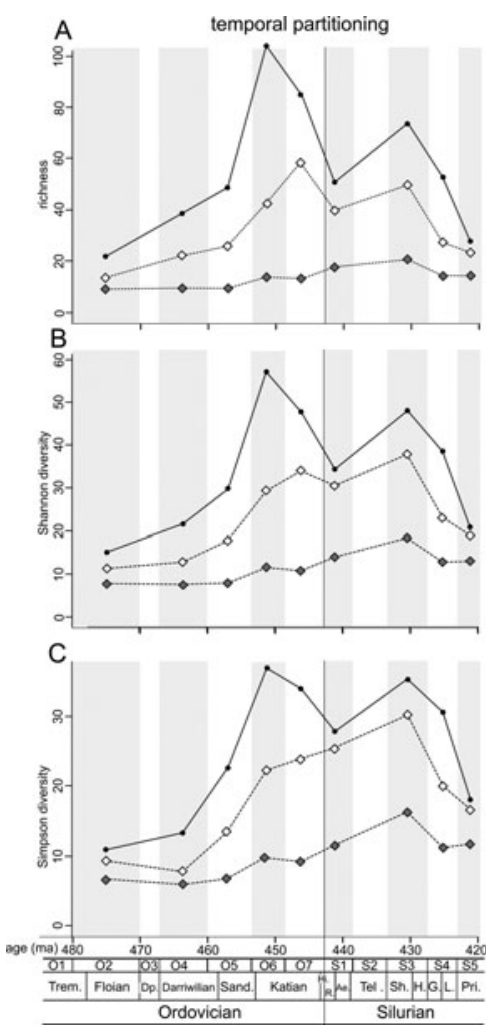

FIGURE 6. Temporal diversity partitioning, which emphasizes the contribution of temporal turnover to regional diversity. Curves are calculated using genus richness and Hill numbers corresponding to the Shannon and Simpson indices (Shannon and Simpson diversity). A three-level hierarchy is used, with mean diversity within lithostratigraphic units (alpha1, gray diamonds), mean diversity in regional stages within a time bin (alpha2, white diamonds), and regional diversity (gamma, black circles). The difference between alpha 1 and alpha 2 reflects the extent of faunal differences between lithostratigraphic units within regional stages, while the difference between alpha2 and gamma reflects faunal differentiation between regional stages. A, Raw genus richness curves. B, Shannon diversity curves. C, Simpson diversity curves. Stage abbreviations are: Dp., Dapingian; Sand., Sandbian; Hi, Hirnantian; R., Rhuddanian; Ae., Aeronian; Tel., Telychian; Sh., Sheinwoodian; H., Homerian; G., Gorstian; L., Ludfordian; Pri., Pridoli.

depositional environments. Siliciclasticdominated lithostratigraphic units show a more rapid diversification than carbonatedominated ones (Fig. 8) but are dominated by just a few brachiopod genera until O5 (UhakuHaljala stages, Darriwilian-Sandbian) (see Supplementary Material 3). The marked increase in siliciclastic-hosted richness in O6 reflects the regional faunal turnover event during this interval (Ainsaar et al. 2004 and references therein). 
TABLE 2. Taxonomic turnover between stages ( $\beta 2)$ measured as a percentage of $\gamma$ diversity and the associated $p$-values. $\beta 2$ was measured using richness, the Shannon diversity, and the Simpson diversity. The values used to produce this table are given in Supplementary Material 3A. Data where $p$-values were below 0.1 are highlighted in gray. NAs denote time bins with insufficient data for analysis, or where bins were not subdivided into multiple stages.

\begin{tabular}{|c|c|c|c|c|c|c|}
\hline & \multicolumn{2}{|c|}{ Richness } & \multicolumn{2}{|c|}{ Shannon diversity } & \multicolumn{2}{|c|}{ Simpson diversity } \\
\hline & $\beta 2_{\mathrm{S}}$ & $\beta 2_{\mathrm{S}} p$-value & $\beta 2_{\text {shan }}$ & $\beta 2_{\text {shan }} p$-value & $\beta 2_{\text {sim }}$ & $\beta 2_{\text {sim }} p$-value \\
\hline C & NA & NA & NA & NA & NA & NA \\
\hline O1 & NA & NA & NA & NA & NA & NA \\
\hline $\mathrm{O} 2$ & 1.57 & 0.09 & 1.33 & 0.51 & 1.17 & 0.97 \\
\hline $\mathrm{O} 3$ & NA & NA & NA & NA & NA & NA \\
\hline $\mathrm{O} 4$ & 1.73 & 0.01 & 1.68 & 0.01 & 1.70 & 0.01 \\
\hline O5 & 1.88 & 0.01 & 1.68 & 0.01 & 1.67 & 0.01 \\
\hline O6 & 2.43 & 0.01 & 1.94 & 0.01 & 1.65 & 0.01 \\
\hline O7 & 1.45 & 0.01 & 1.4 & 0.01 & 1.42 & 0.01 \\
\hline S1 & 1.28 & 0.07 & 1.12 & 0.25 & 1.1 & 0.59 \\
\hline S2 & NA & NA & NA & NA & NA & NA \\
\hline S3 & 1.48 & 0.01 & 1.27 & 0.05 & 1.17 & 0.65 \\
\hline S4 & 1.92 & 0.17 & 1.67 & 0.15 & 1.53 & 0.55 \\
\hline S5 & 1.19 & 1 & 1.1 & 0.93 & 1.09 & 0.97 \\
\hline
\end{tabular}

With stage-level temporal resolution, carbonate- and siliciclastic-hosted richness curves are decoupled beginning during the Katian, during the Oandu Stage (in bin O6), and continuing into the Silurian (Fig. 8). In the Silurian, siliciclastic-hosted brachiopod richness begins to recover from the LOME earlier than carbonate-hosted richness, though both decline toward the end of the Silurian (Fig. 9). However, richness within carbonatedominated lithologies closely reflects the regional richness pattern, suggesting that carbonate lithologies are dominating the regional richness trajectory, particularly in the Ordovician (compare Figs. 5 and 8A).

Lithologic Diversity Partitioning.-The large difference between $\alpha 1$ and $\alpha 2$ suggests that faunal differences between lithostratigraphic units are a major contributor to regional diversity through most of the Ordovician; this trend seems particularly strong during $\mathrm{O} 4-\mathrm{O} 7$, when $\beta 1_{\mathrm{S}}$ is at its highest (Table 3, Fig. 9A). Nevertheless, differentiation between carbonate- and siliciclastic-dominated lithologies $\left(\beta 2_{\mathrm{S}}\right)$ remains an important contributor to diversity (Table 3, Fig. 10A). Most features of the trends in $\alpha_{S}$ and $\beta_{S}$ are also shown by the Shannon and Simpson diversities (Fig. 9B,C), demonstrating that faunal differences apply to the entire abundance distribution of the brachiopod assemblages within lithostratigraphic units and are not restricted to rare taxa.
The Silurian decline in faunal differentiation between lithostratigraphic units $\left(\beta 1_{\mathrm{S}}\right)$ reflects regional-scale homogenization of brachiopod assemblages across environmental gradients accompanied by alpha-diversity increase, consistent with relaxed environmental preferences in Silurian brachiopods. Both siliciclastic- and carbonate-dominated lithologies become dominated by relatively few brachiopod genera, present at high abundances (e.g., Leptaena and Atrypa in bin S3, Dayia in S4, Shaleria and Microsphaeridiorhynchus in S5; see Supplementary Material 4).

To evaluate whether metacommunity faunal heterogeneity differed between siliciclasticand carbonate-dominated lithostratigraphic units, we performed multiplicative diversity partitioning on the two lithologic categories separately. Comparison of alpha and gamma diversity trajectories (Figs. 10A, 11A) suggest that beta diversity among carbonatedominated lithologies is generally higher than among siliciclastic-dominated lithologies and that this contrast is especially pronounced when the Simpson diversity is used, emphasizing the most abundant genera (Fig. 10B,C, and 11B,C). A one-sided Mann-Whitney test using stage-level Simpson diversity data shows that beta diversity between lithostratigraphic units $\left(\beta 1_{\text {sim }}\right)$ is significantly higher in carbonatedominated than in siliciclastic-dominated lithologies $(p=0.03)$. 


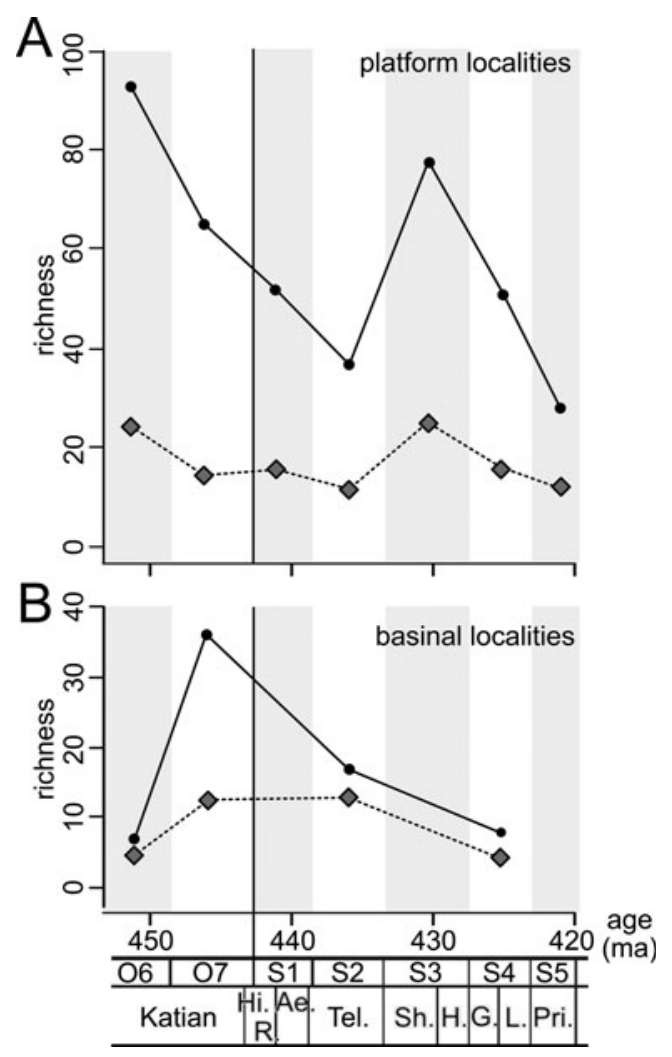

FIGURE 7. Diversity partitioning in platform and basinal localities, defined based on the regional facies boundaries in Fig. 1. Diversity curves are only shown from O6 onward, as this marks the start of the platform differentiation depositional interval (Fig. 3). A two-level hierarchy is used, with genus richness within lithostratigraphic units (gray diamonds) and regional richness in the relevant setting (black circles). A large difference between the two diversity curves represents a larger contribution from beta diversity. Error bars represent $95 \%$ confidence intervals, though these are generally very small. A, Raw genus richness in platform environments. B, Raw genus richness in basinal environments. Stage abbreviations are: Hi, Hirnantian; R., Rhuddanian; Ae., Aeronian; Tel., Telychian; Sh., Sheinwoodian; H., Homerian; G., Gorstian; L., Ludfordian; Pri., Pridoli.

Beta diversity in genus richness among carbonate-dominated lithostratigraphic units $\left(\beta 1_{\mathrm{S}}\right)$ increases consistently through the Dapingian-Katian (time bins O3-O6), though to a slightly lesser extent when the Shannon and Simpson diversities are used (Table 4, Supplementary Material 3C). In siliciclastic lithologies, $\beta 1_{\mathrm{S}}$ is lower than in carbonate-dominated lithologies, and the difference between $\alpha 1$ and $\gamma$ is markedly lower when the Simpson diversity is used (Table 4, Supplementary Material 3D).

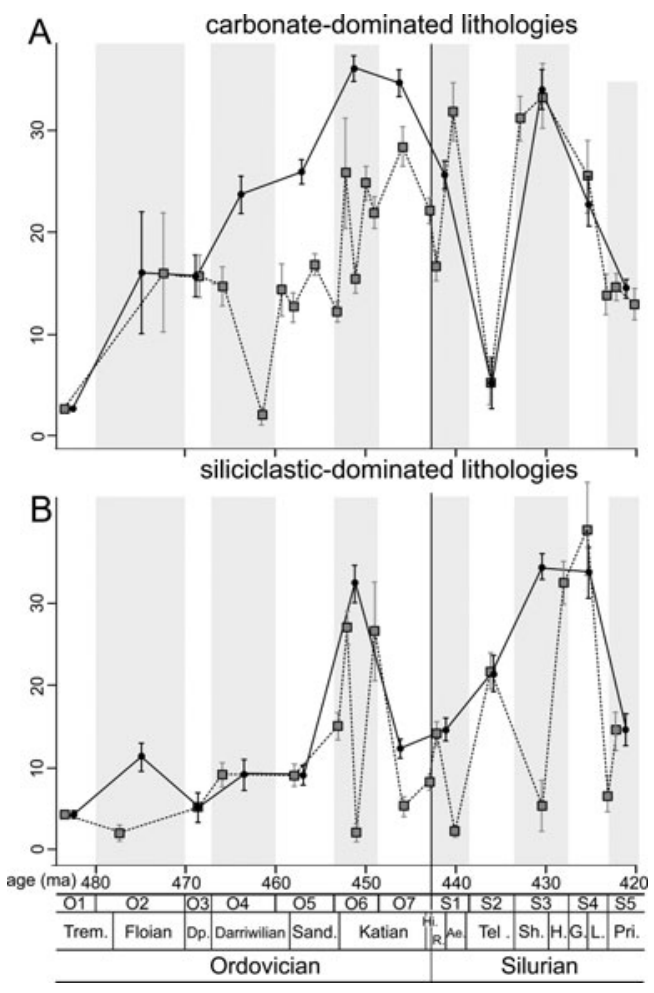

FIGURE 8. Independent coverage-standardized genus richness curves for carbonate- and siliciclastic-dominated lithostratigraphic units, calculated using iNEXT, using both the regional stages (gray rectangles, dotted line) and coarser time-binning (black ovals, solid line) scheme. All curves are coverage-standardized to 0.7. A, Regional genus richness in carbonate-dominated lithologies. B, Regional genus richness in siliciclastic-dominated localities. Stage abbreviations are: Dp., Dapingian; Sand., Sandbian; Hi, Hirnantian; R., Rhuddanian; Ae., Aeronian; Tel., Telychian; Sh., Sheinwoodian; H., Homerian; G., Gorstian; L., Ludfordian; Pri., Pridoli.

This pattern suggests that in siliciclasticdominated lithostratigraphic units, high beta diversity is typically generated among the rarer genera, while in carbonate-dominated lithologies, high beta diversity also affects the commonest genera, implying important differences in assemblage composition between lithostratigraphic units. While time bin O6, where beta diversity peaks, is also the time bin showing highest temporal turnover, we expect this effect to be related to environmental change rather than depth-related differences in evolutionary rates, because onshore and offshore environments have similar origination and extinction rates (Franeck and Liow 2019). 


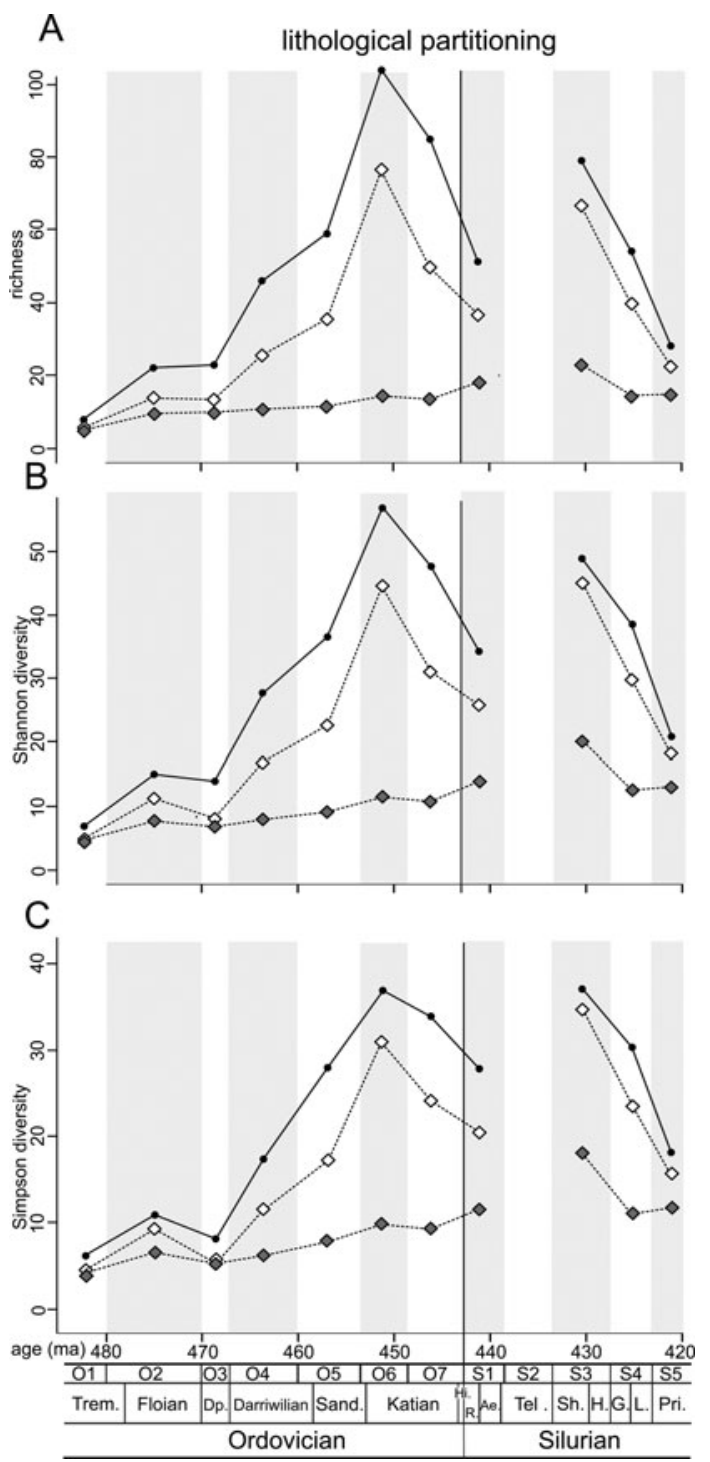

FIGURE 9. Lithologic diversity partitioning, which emphasizes how faunal differences between lithostratigraphic units contribute to regional diversity. Diversity curves were calculated using genus richness and Hill numbers corresponding to the Shannon and Simpson indices. A three-level hierarchy is used, with mean diversity within lithostratigraphic units (alpha1, gray diamonds), mean diversity within carbonate- and siliciclasticdominated lithostratigraphic units (alpha2, white diamonds), and regional diversity (gamma, black circles). The difference between alpha1 and alpha2 reflects the extent of faunal differences between lithostratigraphic units, while the difference between alpha2 and gamma reflects faunal differentiation between carbonate- and siliciclastic-dominated facies. A, Genus richness curves. B, Shannon diversity curves. C, Simpson diversity curves. Stage abbreviations are: Dp., Dapingian; Sand., Sandbian; Hi, Hirnantian; R., Rhuddanian; Ae., Aeronian; Tel., Telychian; Sh., Sheinwoodian; H., Homerian; G., Gorstian; L., Ludfordian; Pri., Pridoli.
TABLE 3. Taxonomic turnover between lithostratigraphic units $\left(\beta 1_{\mathrm{S}}\right)$ and between carbonate- and siliclastic-dominated lithologies $\left(\beta 2_{\mathrm{S}}\right)$, measured using richness, and the associated $p$-values. Data used to produce this table are given in Supplementary Material 3B. Data where $p$-values were below 0.1 are highlighted in gray. NAs denote time bins with insufficient data for analysis, or with data from only one lithological type.

\begin{tabular}{lcccc}
\hline \hline & $\beta 1_{\mathrm{S}}$ & $\beta 1_{\mathrm{S}} p$-value & $\beta 2_{\mathrm{S}}$ & $\beta 2_{\mathrm{S}} p$-value \\
\hline $\mathrm{C}$ & $\mathrm{NA}$ & $\mathrm{NA}$ & $\mathrm{NA}$ & $\mathrm{NA}$ \\
$\mathrm{O} 1$ & 1.08 & 0.91 & 1.45 & 0.01 \\
$\mathrm{O} 2$ & 1.5 & 0.01 & 1.57 & 0.11 \\
O3 & 1.43 & 0.45 & 1.77 & 0.19 \\
O4 & 2.40 & 0.01 & 1.80 & 0.01 \\
O5 & 3.2 & 0.01 & 1.66 & 0.01 \\
O6 & 5.25 & 0.01 & 1.36 & 0.01 \\
O7 & 3.74 & 0.01 & 1.72 & 0.01 \\
S1 & 1.97 & 0.01 & 1.4 & 0.01 \\
S2 & 1.38 & 0.77 & 1.87 & 0.01 \\
S3 & 2.97 & 0.33 & 1.18 & 0.29 \\
S4 & 2.74 & 0.63 & 1.37 & 0.01 \\
S5 & 1.54 & 0.01 & 1.24 & 0.15 \\
\hline
\end{tabular}

The decline in siliciclastic-hosted genus richness and beta diversity from time bins $\mathrm{O} 6$ to $\mathrm{O} 7$ may be attributable to a decline in the number of exposed siliciclastic rock units. In time bin O6, siliciclastic-hosted genus richness and beta diversity are far higher than in time bin O7, but the number of lithostratigraphic units is also higher (10 in time bin O6, compared with 4 in O7).

Responses of Alpha, Beta, and Gamma Diversity to the GOBE and LOME.-The GOBE has relatively little impact on alpha diversity in the eastern Baltic paleobasin. The genus richness of lithostratigraphic units $\left(\alpha_{S}\right)$ shows a small increase over the Ordovician, but this diversification comprises only a small proportion of the regional diversity, which instead is principally generated by environmentally influenced faunal heterogeneity and temporal turnover. The principal Ordovician diversification occurs within both siliciclastic and carbonate environments, and the faunal differences between the carbonate- and siliciclastic-dominated lithologies are a relatively small contributor to regional diversity. However, the LOME seems to have a differential impact on siliciclastic and carbonate facies. There was only a limited recovery from the LOME overall and in carbonate-dominated lithostratigraphic units, though the recovery in siliciclastic lithostratigraphic units is more pronounced. 

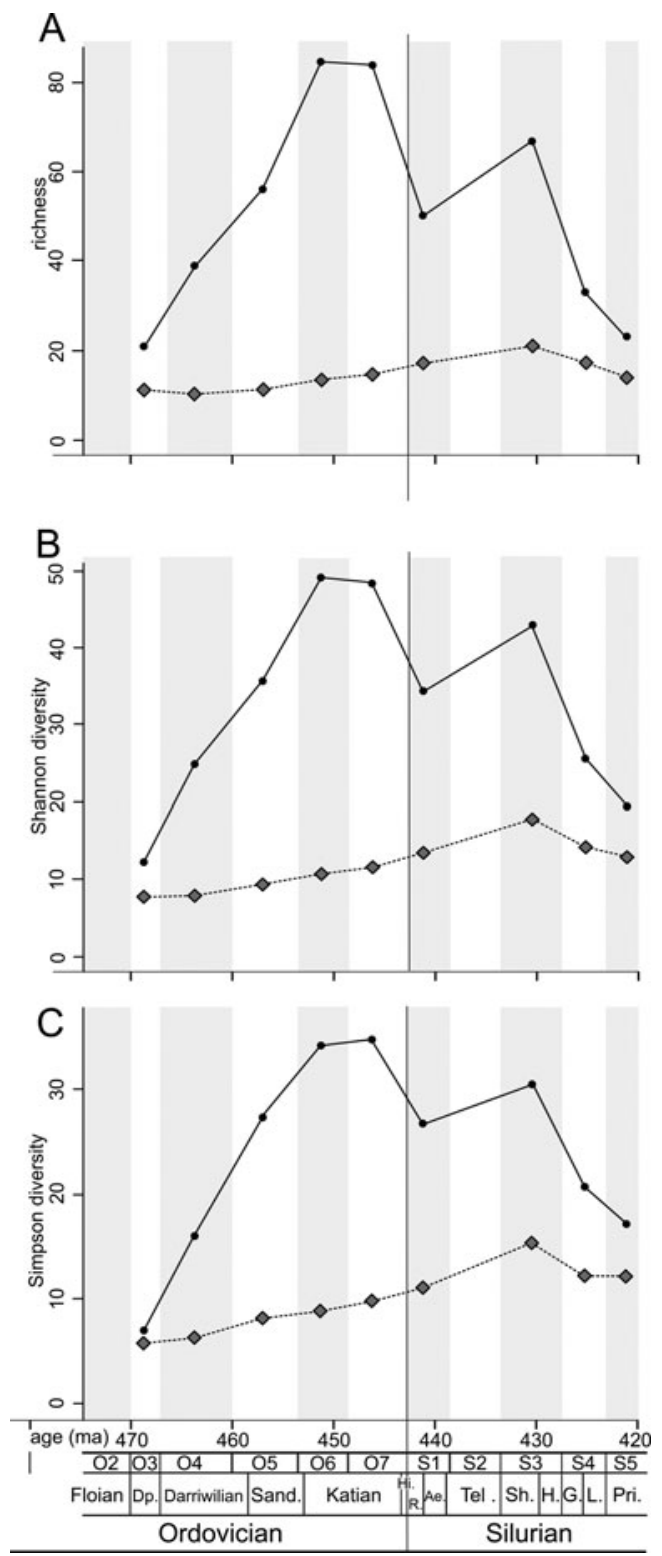

FIGURE 10. Diversity partitioning within carbonatedominated facies, calculated using genus richness and Hill numbers corresponding to the Shannon and Simpson indices. Curves represent mean diversity within carbonate-dominated lithostratigraphic units (alpha, gray diamonds) and regional diversity in carbonatedominated facies (gamma, black circles). The difference between the two curves reflects the degree of faunal differentiation between carbonate-dominated lithostratigraphic units. A, Genus richness curves. B, Shannon diversity curves. C, Simpson diversity curves. Stage abbreviations are: Dp., Dapingian; Sand., Sandbian; Hi, Hirnantian; R., Rhuddanian; Ae., Aeronian; Tel., Telychian; Sh., Sheinwoodian; H., Homerian; G., Gorstian; L., Ludfordian; Pri., Pridoli.
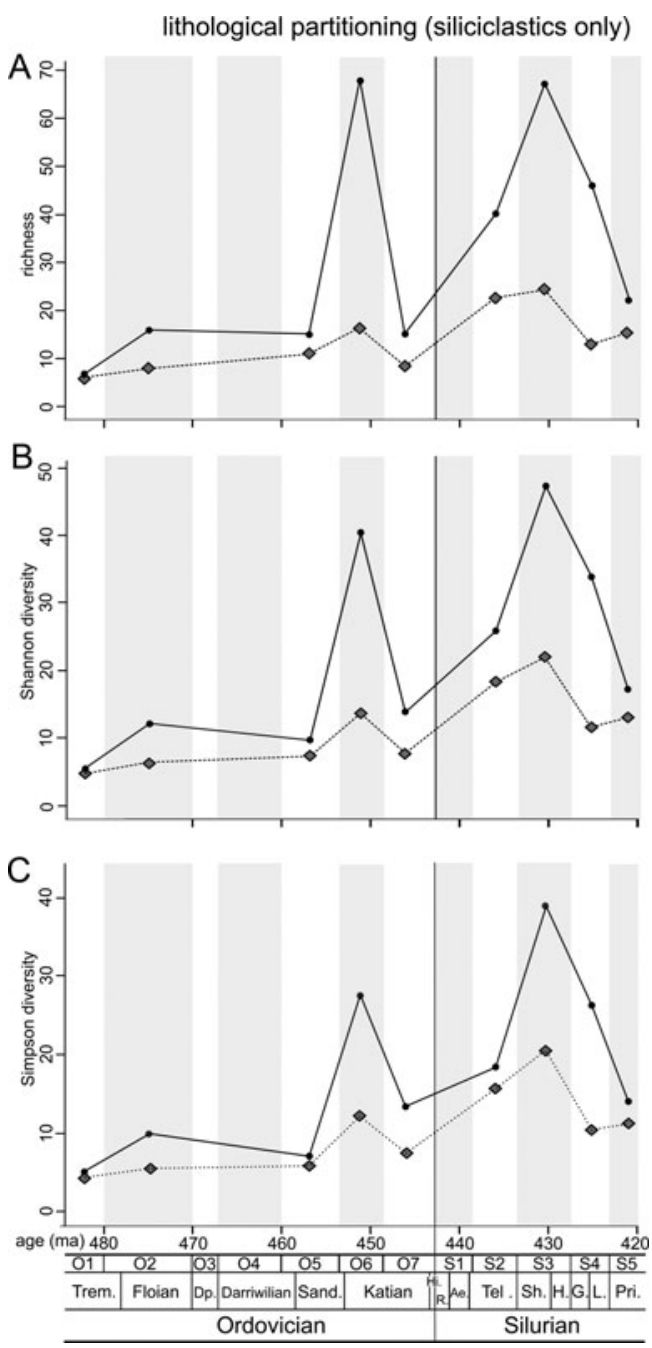

FIGURE 11. Diversity partitioning within siliciclasticdominated facies, calculated using genus richness and Hill numbers corresponding to the Shannon and Simpson indices. Curves represent mean diversity within siliciclastic-dominated lithostratigraphic units (alpha, gray diamonds) and regional diversity in siliciclastic-dominated facies (gamma, black circles). A large difference between the two curves reflects the degree of faunal differentiation between siliciclastic-dominated lithostratigraphic units. A, Genus richness curves. B, Shannon diversity curves. C, Simpson diversity curves. Stage abbreviations are: Dp., Dapingian; Sand., Sandbian; Hi, Hirnantian; R., Rhuddanian; Ae., Aeronian; Tel., Telychian; Sh., Sheinwoodian; H., Homerian; G., Gorstian; L., Ludfordian; Pri., Pridoli.

\section{Discussion}

Diversity patterns in this study show some generalities, such as a Darriwilian diversity increase and further increase in the Sandbian, 
TABLE 4. Beta diversity within carbonate- and siliciclastic-dominated lithostratigraphic units, measured using richness. Full values used as a basis for this table and the Shannon and Simpson diversities are given in Supplementary Material 3C and 3D. Beta diversities with $p$-values lower than 0.1 are highlighted in gray. "NA" denotes time bins with insufficient data for analysis, or containing only a single lithostratigraphic unit in the relevant lithological category.

\begin{tabular}{lccccc}
\hline \hline & \multicolumn{2}{c}{ Carbonate-dominated } & & \multicolumn{2}{c}{ Siliciclastic-dominated } \\
\cline { 2 - 3 } \cline { 5 - 6 } & $\beta 1_{\mathrm{S}}$ & $\beta 1_{\mathrm{S}} p$-value & & $\beta 1_{\mathrm{S}}$ & $\beta 1_{\mathrm{S}} p$-value \\
\hline $\mathrm{C}$ & $\mathrm{NA}$ & $\mathrm{NA}$ & & $\mathrm{NA}$ & $\mathrm{NA}$ \\
$\mathrm{O} 1$ & $\mathrm{NA}$ & $\mathrm{NA}$ & & 1.17 & 1.00 \\
$\mathrm{O} 2$ & $\mathrm{NA}$ & $\mathrm{NA}$ & & 2.00 & 0.01 \\
$\mathrm{O} 3$ & 1.85 & 0.99 & & NA & NA \\
O4 & 3.79 & 0.01 & & NA & NA \\
O5 & 5.03 & 0.01 & & 1.36 & 0.59 \\
O6 & 6.31 & 0.01 & & 4.19 & 0.01 \\
O7 & 5.68 & 0.01 & & 1.80 & 0.03 \\
S1 & 2.94 & 0.01 & & NA & NA \\
S2 & NA & NA & & 1.76 & 0.95 \\
S3 & 3.19 & 0.01 & & 2.75 & 0.85 \\
S4 & 1.94 & 0.15 & & 3.54 & 1.00 \\
S5 & 1.64 & 0.97 & & 1.43 & 0.01 \\
\hline
\end{tabular}

a Late Ordovician diversity peak and a diversity crisis across the Ordovician/Silurian boundary. These patterns are roughly consistent with global and regional richness curves for the GOBE (e.g., Trubovitz and Stigall 2016; Colmenar and Rasmussen 2017; Hints et al. 2018; Rasmussen et al. 2019) and the LOME (e.g., Sheehan 2001; Harper et al. 2013; Rasmussen 2014), including in the Baltic paleobasin (e.g., Nestor et al. 1991; Rasmussen et al. 2007, 2009; Kaljo et al. 2011; Hints et al. 2018). The hierarchical partitioning schemes and multiple diversity indices used here allow us to dissect the roles of environmental heterogeneity and temporal turnover in generating these regional patterns.

Impact of Temporal Turnover on OrdovicianSilurian Diversity Patterns.-Temporal turnover within time bins has a major impact on the regional richness curve for the eastern Baltic paleobasin (Fig. 6A) (an effect also noted by, e.g., Kröger and Lintulaakso [2017]). The impact is largest in time bin O6 (late Sandbian-early Katian) where the total richness strongly exceeds the richness estimates of the respective regional stage bins (Fig. 5). The principal source of temporal substrate changes in the Baltic paleobasin is sea-level change (e.g., Lazauskiene et al. 2003; Harris et al. 2004), and bin $\mathrm{O} 6$ coincides with high faunal differences between the regional Keila-Vormsi stages, which are unconformity-bounded units on the Estonian and Lithuanian shelves. The base Oandu, base Rakvere, and base Nabala stages are karstic over large areas of the North Estonian shelf (Calner et al. 2010), contrasting with the more complete Livonian basin sections. Although exceptionally high turnover rates from this interval are not known from global (Kröger et al. 2019) or paleocontinental-scale (Franeck and Liow 2019) analyses, brachiopod faunas of this interval on the Estonian shelf cluster into highly distinctive time groups, while Livonian basin brachiopod assemblages are not as distinct (Hints et al. 2018).

Immigrations from Avalonia (increasingly from the early Sandbian onward) and Laurentia (increasingly from the late Sandbian onward) also contributed to temporal turnover during O6 (Hints and Harper 2003; Hansen and Harper 2008; Rasmussen and Harper 2011b; Rasmussen et al. 2012). They occurred alongside changes to sediment-transporting sea currents within the Baltic paleobasin (Kiipli et al. 2008, 2009) and reflect the regional "middle Caradoc facies and faunal turnover" (Meidla et al. 1999; Ainsaar et al. 2004). Temporal turnover also makes a large contribution to apparent diversity in time bin S3, which includes two major regional and global biotic turnover events (Ireviken and Mulde events; Calner 2008).

The amplitude and frequency of sea-level change can influence evolutionary rates at global and regional scales. Globally and regionally, high origination and extinction rates cluster at sequence boundaries in shallowwater environments, and contrastingly at maximum flooding intervals in deeper-water environments (Holland 1995, 2020; Holland and Patzkowsky 2002). Sea-level changes can act as a global diversification driver in marine ecosystems, because sea-level falls can isolate marine communities for long periods of time until sea-level increases allow them to disperse (Stigall et al. 2017). In the Baltic paleobasin, repeated cycles of sea-level rise and fall during the Middle Ordovician have also been suggested as a contributor to brachiopod diversification through the same process (Pedersen and 
Rasmussen 2019). Because sea-level change may influence global and regional turnover rates, the completeness of the fossil record, and facies characteristics in parallel, the impact of any one of these factors on temporal turnover cannot be isolated in this study.

Impacts of Facies Changes and Heterogeneity.Alongside temporal turnover, the development and stabilization of an extensive regional carbonate platform in the Baltic paleobasin also enhanced regional diversity, through generating environmental differentiation at multiple spatial scales.

From the late Sandbian-early Katian (O6) time bin throughout the Late Ordovician, faunal difference between siliciclastic- and carbonate-dominated substrates had a large impact on total regional diversity (Fig. 9), and this differentiation is likely to partly reflect broadscale habitat differentiation between platform and basin (Fig. 7). The richness curves of the two lithologic categories run largely parallel during the Lower-Middle Ordovician and most of the Silurian but are divergent during the late Sandbian-Aeronian age (Fig. 8). Relatively low brachiopod diversity in basinal environments is a consistent feature of the diversity curves, and so we interpret it as a predominantly biological signal despite intervals of carbonate dissolution in deep-marine environments (Kiipli and Kiipli 2006). The discrepancy between carbonate-hosted and siliciclastic-hosted brachiopod diversity can be best explained as a consequence of the dichotomy between shallow- and deep-water brachiopod faunas during the Late Ordovician (Hints and Harper 2003; Harper and Hints 2016; see also "Results" section), and additionally as an effect of high temporal turnover in shallow-water siliciclastics during O6.

While differentiation between shelf and basin environments generated broadscale faunal differences (see also Hints and Harper 2003; Kaljo et al. 2011; Harper and Hints 2016; Hints et al. 2018), a large proportion of regional diversification resulted from faunal differentiation between lithostratigraphic units operating at smaller spatial scales. This is more pronounced in carbonate-dominated lithologies than siliciclastic-dominated ones (compare Figs. $10 \mathrm{C}$ and $11 \mathrm{C}$ ), hinting that the higher habitat heterogeneity in shallow-marine carbonate environments was an important regional diversity driver. High beta diversity among carbonate-dominated lithostratigraphic units occurs whichever diversity index is used, underlining that high beta diversity in carbonate-dominated lithologies affects common and rare genera similarly (Fig. 10). By contrast, beta diversity in siliciclastic-dominated environments is strongly influenced by rare taxa, so it declines considerably when the Simpson diversity is used (Fig. 11A,C).

The increased abundance of skeletal macroorganisms (e.g., Põlma 1982; Põlma et al. 1988), including metazoans and macroalgae (Kröger et al. 2020), would have contributed to the platform formation and facies differentiation, both by acting as a source of carbonate clasts and micrite to build a regional carbonate shelf and by producing fine-scale habitat complexity in shoals, reefs, and algal meadows. An example of such a highly complex facies mosaic is the Pirgu Stage carbonates of Estonia and Lithuania (Hints et al. 2005). Additionally, the flat-topped platform geometry amplified the spatiotemporal differentiation of sediments via sea-level fluctuations, such as widespread karst (Calner et al. 2010) and erosion (Kiipli and Kiipli 2020).

The development of a carbonate platform in the Baltic paleobasin was not an isolated event. During the Middle Ordovician, rising sea levels generated extensive shallow-marine carbonate shelves worldwide (Miller et al. 2005). The complex facies mosaic of Baltica is not unique but shows high similarities with coeval tropical carbonate platforms of Laurentia and South China (e.g., Taylor and Sendino 2010; Wang et al. 2012; Kröger et al. 2017a; Jin et al. 2018; McLaughlin et al. 2019), which is evidence for the global scale of the specific conditions of the Late Ordovician-Silurian tropics.

The general characteristics of marine substrates are likely to exert control over long-term, global evolutionary trends. The expansion of carbonate substrate area may have enhanced diversity (Munnecke et al. 2010), perhaps because specific carbonate environments may have evolutionary impacts. Reefs act as sources of new taxa over the Phanerozoic (Kiessling et al. 2010), and an Ordovician expansion of 
carbonate hardgrounds has been suggested as a diversification driver in hard substrate taxa (e.g., Taylor and Wilson 2003; but see also Franeck and Liow 2020). In the Paleozoic, the global balance between the extent of carbonate and siliciclastic substrates may also influence the global balance between extinction and origination (Foote 2006), and the substrate affinities of benthic clades (Miller and Connolly 2001). While regional in scale, our results support the hypothesis that the expansion of shallow-marine carbonate environments in the Ordovician enhanced regional diversity by enhancing substrate heterogeneity in the forms of both differentiation between shelf and basin and finer-scale differentiation within carbonate environments.

Impacts of Broadscale Environmental Changes: Climate and Paleogeography.-Simultaneous diversification in both siliciclastic- and carbonate-dominated environments suggests broadscale, generalized diversification driver (s) affecting both types of lithologies. One of these drivers was repeated sea-level oscillations, which promoted allopatric speciation in brachiopods (Lam et al. 2018; Stigall 2018; Pedersen and Rasmussen 2019); the long-term, global climatic cooling trend was another (Rasmussen et al. 2019).

At a global scale, Ordovician climatic cooling probably released environmental controls on the growth of skeletal organisms, allowing increased diversification (e.g., see Trotter et al. 2008; Kröger 2017; Edwards 2019; Rasmussen et al. 2019). The shift of Baltica toward the tropics brought regional warming but kept the Baltic paleobasin within this optimal temperature range (Cocks and Torsvik 2005; Dronov and Rozhnov 2007).

The development of a carbonate platform in the Baltic paleobasin and the impacts on regional diversity were ultimately a result of Baltica's plate-tectonic drift toward the tropics. But time-specific climatic constraints within the tropical realm, namely the intensity of ocean currents and levels of global SST, oxygenation, and $\mathrm{pH}$, controlled the details of how this platform accommodated, which organisms produced the carbonate sediments, and the characteristics of their facies mosaic. These processes generated the conditions for the development of tropical carbonate platforms and facies mosaics in the Baltic paleobasin as well as in Laurentia and South China (see earlier discussion). Hence, as well as releasing environmental constraints, global cooling during the Ordovician combined with other regional-scale environmental changes to enhance biodiversity through intensified biologically mediated carbonate production and the development of heterogeneous carbonate environments.

Regional Response to the LOME.-A global signature of the Ordovician-Silurian transition is a general shift from highly differentiated to cosmopolitan faunas, including in brachiopods (e.g., Sheehan and Coorough 1990; Darroch and Wagner 2015). The end-Ordovician extinction led to a global decline in provincialism, with genera lost during the extinction replaced by those dispersing from elsewhere (Sheehan 1975; Krug and Patzkowsky 2007; Finnegan et al. 2016; Congreve et al. 2019; Penny and Kröger 2019; Rasmussen et al. 2019). Sheehan (1975), discussing North America, and Rasmussen and Harper (2011b), discussing the global record, both suggest that the LOME led to the loss of shallow-marine specialist brachiopod genera, which were replaced by assemblages of presumably more eurytopic genera with broader geographic and depth distributions.

This is also evident in the eastern Baltic paleobasin. Notably, mean alpha diversity (i.e., diversity within lithostratigraphic units) is largely unaffected by the extinction, and instead the regional diversity decline principally consists of a reduction in faunal differentiation between lithostratigraphic units and carbonate- and siliciclastic-dominated lithologies after the Hirnantian, alongside a decline in richness at platform localities (Figs. 6A and 9). In this context, the particular role of Baltica's late Katian-Hirnantian deeper-water brachiopods, which became important during Silurian recovery in shallow-water habitats and on Laurentia, needs to be emphasized (Rasmussen et al. 2010, 2012; Rasmussen and Harper 2011a,b; Harper et al. 2013). This study corroborates the finding of these previous works that the evolutionary postextinction shift in 
brachiopods had simultaneous paleogeographic and paleoecological dimensions, with shifting habitats among clades.

Globally, the biotic recovery from the LOME was protracted, and Silurian global richness never returned to Ordovician levels (Rasmussen et al. 2019). This global pattern is also reflected in the Baltic paleobasin (Figs. 5, 6A). As noted in previous studies (e.g., Harper et al. 2015; Harper and Hints 2016; Hints et al. 2018), the regional faunal homogenization was long-lived, and while regional diversity recovered during the early Silurian, it never returned to Ordovician values. In the Silurian, while the carbonate platform persisted in the Baltic paleobasin, faunal differentiation between lithostratigraphic units had a persistently reduced impact on regional diversity, with generally more similar brachiopod assemblages occupying siliciclastic and carbonate environments. The Silurian decline in faunal differentiation between lithologies, combined with the rise of more cosmopolitan brachiopod assemblages, suggests that habitat heterogeneity became a less important driver of regional diversity than it had been in the Ordovician.

\section{Conclusions}

1. The development of a carbonate shelf in the eastern Baltic paleobasin during the Middle Ordovician was one of several important drivers of regional diversification, and this link is largely a result of high faunal heterogeneity (beta diversity) between lithostratigraphic units in carbonate-dominated environments. Coeval carbonate development occurred at other localities worldwide, and our study examines the processes that may have driven regional diversity in these environments.

2. Temporal changes in paleoenvironment (principally due to sea-level change) and faunal composition (due to migration, origination, and extinction) can have a major impact on regional diversity curves, but this impact can be quantified using hierarchical diversity partitioning.

3. Substrate heterogeneity emerges as a consistent regional diversification driver over the Ordovician, though its effects are modulated by sea level, niche breadth, and environmental stressors. Although the Baltic paleobasin retained its heterogeneous carbonate shelf environment through the Silurian, an increase in the dominance of brachiopods with broad environmental and geographic distributions may have reduced the impact of habitat heterogeneity during the Silurian recovery from the LOME.

\section{Acknowledgments}

We thank L. Hints and L. Ainsaar for constructive discussion during development of this study, U. Toom for help with locating relevant literature, $S$. Scholze for data entry into the Paleobiology Database over the course of this study, and D. Matthews for assistance with compiling lithologic data. This paper is part of the project "Ecological Engineering as a Biodiversity Driver in Deep Time," funded by the Academy of Finland, and is a contribution to the IGCP program 653 "The Onset of the Great Ordovician Biodiversification Event." O.H. acknowledges support from the Estonian Research Council grant PRG836.

\section{Data Availability Statement}

Data and R scripts for this study are available at: A. Penny, O. Hints, and B. Kröger, 2020, Data and code for: Carbonate shelf development and early Paleozoic benthic diversity in Baltica: a hierarchical diversity partitioning approach using brachiopod data, Dryad dataset, https://doi.org/10.5061/dryad.1g1jwstv0.

\section{Literature Cited}

Aaloe, A., and H. Nestor. 1977. Biohermal facies in the Juuru Stage (Lower Llandoverian) in Northwest Estonia. Pp. 71-88 in D. Kaljo, ed. Facies and fauna of the Baltic Silurian. Academy of Sciences of the Estonian S.S.R. Institute of Geology, Tallinn. [In Russian.]

Ainsaar, L., T. Meidla, and T. Martma. 2004. The Middle Caradoc facies and faunal turnover in the Late Ordovician Baltoscandian palaeobasin. Palaeogeography, Palaeoclimatology, Palaeoecology 210:119-133.

Alroy, J. 2014. Accurate and precise estimates of origination and extinction rates. Paleobiology 40, 374-397.

Bauert, H., O. Hints, T. Meidla, and P. Männik. 2014. Fourth Annual Meeting of the IGCP 591, Estonia 10-19 June 2014. Abstracts and Field Guide. P. 202.

Brocklehurst, N., M. O. Day, J. Fröbisch. 2018. Accounting for differences in species frequency distributions when calculating beta 
diversity in the fossil record. Methods in Ecology and Evolution 9:1409-1420.

Calner, M. 2008. Silurian global events-at the tipping point of climate change. Pp. 21-58 in A. M. T. Elewa, ed. Mass extinction. Springer, Berlin.

Calner, M., O. Lehnert, and M. Joachimski. 2010. Carbonate mud mounds, conglomerates, and sea-level history in the Katian (Upper Ordovician) of central Sweden. Facies 56:157-172.

Calner, M., P. Ahlberg, O. Lehnert, and M. Erlström. 2013. The Lower Palaeozoic of southern Sweden and the Oslo Region, Norway. Field Guide for the 3rd Annual Meeting of the IGCP project 591:1-96.

Cocks, L. R. M., and T. H. Torsvik. 2005. Baltica from the late Precambrian to mid-Palaeozoic times: the gain and loss of a terrane's identity. Earth-Science Reviews 72:39-66.

Colmenar, J., and C. M. Ø. Rasmussen. 2017. A Gondwanan perspective on the Ordovician Radiation constrains its temporal duration and suggests first wave of speciation, fuelled by Cambrian clades. Lethaia 51:286-295.

Congreve, C. R., A. Z. Krug, and M. E. Patzkowsky. 2019. Evolutionary and biogeographical shifts in response to the Late Ordovician Mass Exinction. Palaeontology 62:267-285.

Darroch, S. A. F., and P. J. Wagner. 2015. Response of beta diversity to pulses of Ordovician-Silurian mass extinction. Ecology 96:532-549.

Dronov, A., and S. Rozhnov. 2007. Climatic changes in the Baltoscandian basin during the Ordovician: sedimentological and palaeontological aspects. Acta Palaeontologica Sinica 46:108-113.

Dronov, A., T. Meidla, L. Ainsaar, and O. Tinn. 2000. The Billingen and Volkhov Stages in the northern East Baltic: detailed stratigraphy and lithofacies zonation. Proceedings of the Estonian Academy of Sciences, Geology 49:3-16.

Dronov, A. V., L. Ainsaar, D. Kaljo, T. Meidla, T. Saadre, and R. Einasto. 2011. Ordovician of Baltoscandia: facies, sequences and sea-level changes. Pp. 143-150 in J. C. Gutiérrez-Marco, I. Rábano, and D. García-Bellido, eds. Ordovician of the world. Cuadernos del Museo Geominero, 14. Instituto Geológico y Minero de España, Madrid.

Ebbestad, J. O. E., L. M. Wickström, and A. E. S. Högström. 2007. WOGOGOB 2007, 9th meeting of the working group on Ordovician geology of Baltoscandia. Field Guide and Abstracts. Sveriges Geologiska Undersökning, Rapporter och Meddelanden 128.

Edwards, C. T. 2019. Links between early Paleozoic oxygenation and the Great Ordovician Biodiversification Event (GOBE): a review. Palaeoworld 28:37-50.

Einasto, R. 1986. Main stages of development and facies models of the East Baltic Silurian pericontinental basin. Pp. 37-54 in E. Radionova, R. Einasto, D. Kaljo, and E. Klaaman, eds. Theory and practice of ecostratigraphy. Valgus, Tallinn.

Einasto, R., and H. Nestor. 1973. Obshchaja skhema fazialnoj sonalnosti Baltiijskogo bassejna $\mathrm{v}$ silure $\mathrm{i}$ ee paleogeografosedimentologicheskaja interpretazija. Pp. 38-40 in Fazii I Geokhemija Karbonatnykh Otloshenij. Academy of Sciences of the S.S.S.R, Leningrad.

Finnegan, S., C. M. Ø. Rasmussen, and D. A. T. Harper. 2016. Biogeographic and bathymetric determinants of brachiopod extinction and survival during the Late Ordovician mass extinction. Proceedings of the Royal Society of London B 283:20160007.

Foote, M. 2006. Substrate affinity and diversity dynamics of Paleozoic marine animals. Paleobiology 32:345-366.

Franeck, F., and L. H. Liow. 2019. Dissecting the paleocontinental and paleoenvironmental dynamics of the great Ordovician biodiversification. Paleobiology 45:221-234.

Franeck, F., and L. H. Liow. 2020. Did hard substrate taxa diversify prior to the Great Ordovician Biodiversification Event? Palaeontology 63:675-687.

Gaston, K. J. 2010. Valuing common species. Science 327:154-156.
Gaston, K. J., T. M. Blackburn, J. J. D. Greenwood, R. D. Gregory, M. Quinn, and J. H. Lawton. 2000. Abundance-occupancy relationships. Journal of Applied Ecology 37:39-59.

Good, I. J. 1953. The population frequencies of species and the estimation of population parameters. Biometrika 40, 237-264.

Gradstein, F., J. Ogg, M. Schmitz, and G. Ogg. 2012. The geologic time scale 2012. Elsevier, Amsterdam.

Hammer, Ø. 2003. Biodiversity curves for the Ordovician of Baltoscandia. Lethaia 36:305-314.

Hansen, J., and D. A. T. Harper. 2008. The late Sandbian-earliest Katian (Ordovician) brachiopod immigration and its influence on the brachiopod fauna in the Oslo Region, Norway. Lethaia 41:25-35.

Harper, D. A. T., and L. Hints. 2016. Hirnantian (Late Ordovician) brachiopod faunas across Baltoscandia: A global and regional context. Palaeogeography, Palaeoclimatology, Palaeoecology 444:71-83.

Harper, D. A. T., C. M. Ø. Rasmussen, M. Liljeroth, R. B. Blodgett, Y. Candela, J. Jin, I. G. Percival, J. Rong, E. Villas, and R.-B. Zhan. 2013. Biodiversity, biogeography and phylogeography of Ordovician rhynchonelliform brachiopods. Pp. 127-144 in D. A. T. Harper and T. Servais, eds. Early Palaeozoic biogeography and palaeogeography. Geological Society of London Memoir 38.

Harper, D. A. T., R. -B. Zhan, and J. Jin. 2015. The Great Ordovician Biodiversification Event: reviewing two decades of research on diversity's big bang illustrated by mainly brachiopod data. Palaeoworld 24:75-85.

Harris, M. T., P. M. Sheehan, L. Ainsaar, L. Hints, P. Männik, J. Nõlvak, and M. Rubel. 2004. Upper Ordovician sequences of western Estonia. Palaeogeography, Palaeoclimatology, Palaeoecology 210:135-148.

Hautmann, M. 2014. Diversification and diversity partitioning. Paleobiology 40:162-176.

Hill, M. O. 1973. Diversity and evenness: a unifying notation and its consequences. Ecology 54:427-432.

Hints, L., and D. A. T. Harper. 2003. Review of the Ordovician rhynchonelliformean Brachiopoda of the East Baltic: their distribution and biofacies. Bulletin of the Geological Society of Denmark 50:29-43.

Hints, L., T. Meidla, J. Nõlvak, and L. Sarv. 1989. Some specific features of the Late Ordovician evolution in the Baltic paleobasin. Proceedings of the Academy of Sciences of the Estonian SSR, Geoloogia 38:87-92.

Hints, L., A. Oraspõld, and J. Nõlvak. 2005. The Pirgu regional stage (Upper Ordovician) in the East Baltic: lithostratigraphy, biozonation, and correlation. Proceedings of the Estonian Academy of Sciences, Geology 54:225-259.

Hints, L., D. A. T. Harper, and J. Paškevičius. 2018. Diversity and biostratigraphic utility of Ordovician brachiopods in the east Baltic. Estonian Journal of Earth Sciences 67:176-191.

Hints, O., M. Isakar, U. Toom, 2019. A national geoscience data platform and its application in paleobiodiversity studies: experiences from Estonia. Biodiversity Information Science and Standards 3:1-3.

Hofmann, R., M. Tietje, and M. Aberhan. 2019. Diversity partitioning in Phanerozoic benthic marine communities. Proceedings of the National Academy of Sciences USA 116:79-83.

Holland, S. M. 1995. The stratigraphic distribution of fossils. Paleobiology 21:92-109.

Holland, S. M. 2010. Additive diversity partitioning in palaeobiology: revisiting Sepkoski's question. Palaeontology 53:1237-1254.

Holland, S. M. 2020. The stratigraphy of mass extinctions and recoveries. Annual Review of Earth and Planetary Sciences 48:3.1-3.23.

Holland, S. M., and M. E. Patzkowsky. 2002. Stratigraphic variation in the timing of first and last occurrences. Palaios 17:134-146.

Hsieh, T. C., K. H. Ma, and A. Chao. 2016. iNEXT: an R package for rarefaction and extrapolation of species diversity (Hill numbers). Methods in Ecology and Evolution 7:1451-1456. 
Jaanusson, V. 1976. Faunal dynamics in the Middle Ordovician (Viruan) of Balto-Scandia. Pp. 301-326 in The Ordovician system: proceedings of a Palaeontological Association symposium. University of Wales Press and National Museum of Wales, Cardiff.

Jin, J., R. Zhan, and R. Wu. 2018. Equatorial cold-water tongue in the Late Ordovician. Geology 46:9, 759-762.

Johnson, M. E. 2006. Relationship of Silurian sea-level fluctuations to oceanic episodes and events. GFF 128:115-121.

Jost, L. 2007. Partitioning diversity into independent alpha and beta components. Ecology 88:2427-2439.

Jost, L., P. DeVries, T. Walla, H. Greeney, A. Chao, and C. Ricotta. 2010. Partitioning diversity for conservation analyses. Biodiversity Research 16:65-76.

Kaljo, D., L. Hints, O. Hints, P. Männik, T. Martma, and J. Nõlvak. 2011. Katian prelude to the Hirnantian (Late Ordovician) mass extinction: a Baltic perspective. Geological Journal 477:464-477.

Kaminskas, D., D. Michelevičius, and N. Blažauskas. 2015. New evidence of an early Pridoli barrier reef in the southern part of Baltic Silurian basin based on three-dimensional seismic survey, Lithuania. Estonian Journal of Earth Sciences 64:47-55.

Kiessling, W., E. Flügel, and J. Golonka. 2003. Patterns of Phanerozoic carbonate platform sedimentation. Lethaia 36:195-226.

Kiessling, W., C. Simpson, and M. Foote. 2010. Reefs as cradles of evolution and sources of biodiversity in the Phanerozoic. Science 327:196-198.

Kiipli, E., and T. Kiipli. 2006. Carbonate distribution in the East Baltic deep shelf in the late Ordovician-early Silurian. GFF 128:147152.

Kiipli, E., and T. Kiipli. 2020. Hirnantian sea-level changes in the Baltoscandian Basin, a review. Palaeogeography, Palaeoclimatology, Palaeoecology 540:109524.

Kiipli, E., T. Kiipli, and T. Kallaste. 2004. Bioproductivity rise in the East Baltic epicontinental sea in the Aeronian (Early Silurian). Palaeogeography, Palaeoclimatology, Palaeocology 205:255-272.

Kiipli, E., T. Kallaste, and T. Kiipli. 2008. Hydrodynamic control of sedimentation in the Ordovician (Arenig-Caradoc) Baltic Basin. Lethaia 41:127-136.

Kiipli, E., T. Kiipli, and T. Kallaste. 2009. Reconstruction of currents in the Mid-Ordovician-Early Silurian central Baltic Basin using geochemical and mineralogical indicators. Geology 37:271-274.

Kiipli, E., T. Kiipli, T. Kallaste, and T. Märss. 2016. Chemical weathering east and west of the emerging Caledonides in the SilurianEarly Devonian, with implications for climate. Canadian Journal of Earth Sciences 53:774-780.

Kiipli, E., T. Kiipli, T. Kallaste, and S. Pajusaar. 2017. Trace elements indicating humid climatic events in the Ordovician-early Silurian. Geochemistry 77:625-631.

Kiipli, T., E. Kiipli, T. Kallaste, R. Hints, P. Somelar, and K. Kirsimäe. 2007. Altered volcanic ash as an indicator of marine environment, reflecting $\mathrm{pH}$ and sedimentation rate - example from the Ordovician Kinnekulle Bed of Baltoscandia. Clays and Clay Minerals 55:177-188

Kocsis, Á. T. 2017. icosa: global triangular and penta-hexagonal grids based on tessellated icosahedra, v. 0.9.81. https://cran.rproject.org/web/packages/icosa/index.html, accessed 13 July 2019.

Koleff, P., K. J. Gaston, and J. J. Lennon. 2003. Measuring beta diversity for presence-absence data. Journal of Animal Ecology 72:367382.

Kröger, B. 2017. Changes in the latitudinal diversity gradient during the Great Ordovician Biodiversification Event. Geology 46:44-47.

Kröger, B., and K. Lintulaakso. 2017. RNames, a stratigraphical database designed for the statistical analysis of fossil occurrences - the Ordovician diversification as a case study. Palaeontologia Electronica 20:1-12.
Kröger, B., L. Hints, O. Lehnert, P. Männik, and M. Joachimski. 2014. The early Katian (Late Ordovician) reefs near Saku, northern Estonia and the age of the Saku Member, Vasalemma Formation. Estonian Journal of Earth Sciences 63:271-276.

Kröger, B., J. O. R. Ebbestad, and O. Lehnert. 2016. Accretionary mechanisms and temporal sequence of formation of the Boda Limestone mud-mounds (Upper Ordovician), Siljan District, Sweden. Journal of Sedimentary Research 86:363-379.

Kröger, B., A. Desrochers, and A. Ernst. 2017a. The reengineering of reef habitats during the Great Ordovician Biodiversification Event. Palaios 32:584-599.

Kröger, B., L. Hints, and O. Lehnert. 2017b. Ordovician reef and mound evolution: the Baltoscandian picture. Geological Magazine 154:683-706.

Kröger, B., F. Franeck, and C. M. Ø. Rasmussen. 2019. The evolutionary dynamics of the early Palaeozoic marine biodiversity accumulation. Proceedings of the Royal Society of London B 286:20191634.

Kröger, B., A. Penny, Y. Shen, and A. Munnecke. 2020. Algae, calcitarchs and the Late Ordovician Baltic limestone facies of the Baltic Basin. Facies 66:1-14.

Krug, A. Z., and M. E. Patzkowsky. 2007. Geographic variation in turnover and recovery from the Late Ordovician mass extinction. Paleobiology 33:435-454.

Lam, A. R., and A. L. Stigall. 2015. Pathways and mechanisms of Late Ordovician (Katian) faunal migrations of Laurentia and Baltica. Estonian Journal of Earth Sciences 64:62-67.

Lam, A. R., A. L. Stigall, and N. J. Matzke. 2018. Dispersal in the Ordovician: speciation patterns and paleobiogeographic analyses of brachiopods and trilobites. Palaeogeography, Palaeoclimatology, Palaeoecology 489:147-165.

Lande, R. 1996. Statistics and partitioning of species diversity, and similarity among multiple communities. Oikos 76:5-13.

Lazauskiene, J., S. Sliaupa, A. Brazauskas, and P. Musteikis. 2003. Sequence stratigraphy of the Baltic Silurian succession: tectonic control on the foreland infill. Pp. 95-115 in T. McCann and A. Saintot, eds. Tracing tectonic deformation using the sedimentary record. Geological Society of London Special Publication 208.

Lindskog, A., M. M. Costa, C. M. Ø. Rasmussen, J. N. Connelly, and M. E. Eriksson. 2017. Refined Ordovician timescale reveals no link between asteroid breakup and biodiversification. Nature Communications 8:1-8.

Liow, L. H., and J. D. Nichols. 2010. Estimating rates and probabilities of origination and extinction using taxonomic occurrence data: capture-mark-recapture (CMR) approaches. Quantitative Methods in Paleobiology. Paleontological Society Papers 16:8194.

Magurran, A. E. 2004. Measuring biological diversity. Blackwell Science, Oxford.

Männik, P. 2014. The Silurian system in Estonia. Pp. 123-128 in H. Bauert, O. Hints, T. Meidla, and P. Männik, eds. Fourth Annual Meeting of the IGCP 591, Estonia 10-19 June 2014. Abstracts and Field Guide.

McLaughlin, P. I., P. Emsbo, C. E. Brett, A. M. Bancroft, A. Desrochers, and T. R. A. Vandenbroucke. 2019. The rise of pinnacle reefs: a step change in marine evolution triggered by perturbation of the global carbon cycle. Earth and Planetary Science Letters 515:13-25.

Meidla, T., L. Ainsaar, L. Hints, O. Hints, T. Martma, and J. Nõlvak. 1999. The mid-Caradocian biotic and isotopic event in the Ordovician of the East Baltic. Acta Universitatis Carolinae- Geologica 1/2:503-506

Miller, A. I., and S. R. Connolly. 2001. Substrate affinities of higher taxa and the Ordovician Radiation. Paleobiology 27:768-778.

Miller, K. G., M. A. Kominz, J. V Browning, J. D. Wright, G. S. Mountain, M. E. Katz, P. J. Sugarman, B. S. Cramer, 
N. Christie-Blick, and S. F. Pekar. 2005. The Phanerozoic record of global sea-level change. Science 310:1293-1299.

Munnecke, A., M. Calner, D. A. T. Harper, and T. Servais. 2010. Ordovician and Silurian sea-water chemistry, sea level, and climate: a synopsis. Palaeogeography, Palaeoclimatology, Palaeoecology 296:389-413.

Nestor, H., and R. Einasto. 1977. Fazialno-sedimentologicheskaja model silursijskogo Peleobaltijskogo bessejna. Pp. 89-121 in D. Kaljo, ed. Fazii I Fauna Silura Pribaltiki. Academy of Sciences of the Estonian S.S.R. Institute of Geology, Tallinn.

Nestor, H., and R. Einasto. 1982. Application of the shelf and slope concepts to the Silurian Baltic basin. Pp. 17-24 in D. Kaljo and E. Klaamann, eds. Ecostratigraphy of the East Baltic Silurian. Valgus, Tallinn.

Nestor, H., and R. Einasto. 1997. Ordovician and Silurian carbonate sedimentation basin. Pp. 192-204 in A. Raukas and A. Teedumäe, eds. Geology and mineral resources of Estonia. Estonian Academy Publishers, Tallinn.

Nestor, H. E., E. R. Klaamann, T. R. Meidla, P. E. Männik, V. V. Nestor, J. R. Nõlvak, M. P. Rubel, L. J. Sarv, and L. M. Hints. 1991. Dinamika fauny v Baltijskom bassejne na granice ordovika i silura. Pp. 68-79 in Major biological events in Earth history. Transactions of the 32nd session of the All-Union Palaeontological Society. [In Russian]

Nichols, J. D., and K. H. Pollock. 1983. Estimating taxonomic diversity, extinction rates, and speciation rates from fossil data using capture-recapture models. Paleobiology 9:150-163.

Nielsen, A. T. 2004. Ordovician sea level changes: a Baltoscandian perspective. Pp. 84-93 in B. D. Webby, F. Paris, M. Droser, and I. Percival, eds. The Great Ordovician Biodiversification Event. Columbia University Press, New York.

Oksanen, J., F. G. Blanchet, M. Friendly, R. Kindt, P. Legendre, D. McGlinn, P. R. Minchin, R. B. O'Hara, G. L. Simpson, P. Solymos, M. H. H. Stevens, E. Szoecs, and H. Wagner. 2018. vegan: community ecology package, $\mathrm{R}$ package version 2.5.2. https://CRAN.R-project.org/package=vegan.

Orviku, K. 1940. Lithologie der Tallinna-Serie (Ordovizium, Estland) I. Tartu Ülikooli Geoloogia-Instituudi Toimetused 58: 1-224.

Paškevičius, B. 1997. The geology of the Baltic republics. Vilnius University and Geological Survey of Lithuania, Vilnius.

Patzkowsky, M. E., and S. M. Holland. 2007. Diversity partitioning of a Late Ordovician marine biotic invasion: controls on diversity in regional ecosystems. Paleobiology 33:295-309.

Patzkowsky, M. E., and S. M. Holland. 2012. Stratigraphic paleobiology: understanding the distribution of fossil taxa in time and space. University of Chicago Press, Chicago.

Pedersen, M., and C. M. Ø. Rasmussen. 2019. The glacially induced Middle Ordovician rise of the Plectambonitoidea (Brachiopoda) and the phylogenetic placement of the Baltic genus Ukoa. Palaeogeography, Palaeoclimatology, Palaeoecology 534:109319.

Penny, A., and B. Kröger. 2019. Impacts of spatial and environmental differentiation on early Palaeozoic marine biodiversity. Nature Ecology and Evolution 3:1655-1660.

Põlma, L. 1982. Comparative lithology of the Ordovician carbonate rocks in the northern and middle east Baltic. Valgus, Tallinn. [In Russian]

Põlma, L., L. Sarv, and L. Hints. 1988. Litologia i fauna tipovih rasvesov karadokskogo jarusa v severnoi estonii. Valgus, Tallinn.

Porębski, S. J., R. Anczkiewicz, M. Paszkowski, S. Skompski, A. Kędzior, S. Mazur, J. Szczepański, A. Buniak, and Z. Mikołajewski. 2019. Hirnantian icebergs in the subtropical shelf of Baltica: evidence from sedimentology and detrital zircon provenance. Geology 47:284-288.

Rasmussen, C. M. Ø. 2014. Phylogeography of Ordovician-Silurian rhynchonelliformean brachiopods: tracking higher order distributional patterns, radiations and extinctions in 4D. GFF 136:223-228.
Rasmussen, C. M. Ø., and D. A. T. Harper. 2011a. Did the amalgamation of continents drive the end Ordovician mass extinctions? Palaeogeography, Palaeoclimatology, Palaeoecology 311:48-62.

Rasmussen, C. M. Ø., and D. A. T. Harper. 2011b. Interrogation of distributional data for the End Ordovician crisis interval: where did disaster strike? Geological Journal 46:478-500.

Rasmussen, C. M. Ø., J. Hansen, and D. A. T. Harper. 2007. Baltica: a mid Ordovician diversity hotspot. Historical Biology 19:255-261.

Rasmussen, C. M. Ø., A. T. Nielsen, and D. A. T. Harper. 2009. Ecostratigraphical interpretation of lower Middle Ordovician East Baltic sections based on brachiopods. Geological Magazine 146:717-731.

Rasmussen, C. M. Ø., J. О. R. Ebbestad, and D. A. T. Harper. 2010. Unravelling a Late Ordovician pentameride (Brachiopoda) hotspot from the Boda Limestone, Siljan district, central Sweden. GFF 132:133-152.

Rasmussen, C. M. Ø., D. A. T. Harper, and R. Blodgett. 2012. Late Ordovician brachiopods from west-central Alaska: systematics, ecology and palaeobiogeography. Fossils and Strata 58:1-103.

Rasmussen, C. M. Ø., B. Kröger, M. L. Nielsen, and J. Colmenar. 2019. Cascading trend of Early Paleozoic marine radiations paused by Late Ordovician extinctions. Proceedings of the National Academy of Sciences USA 116:7207-7213.

Raukas, A., and A. Teedumäe. 1997. Geology and mineral resources of Estonia. Estonian Academy Publishers, Tallinn.

Reddin, C. J., J. H. Bothwell, and J. J. Lennon. 2015. Between-taxon matching of common and rare species richness patterns. Global Ecology and Biogeography 24:1476-1486.

Ricotta, C. 2005. On hierarchical diversity decomposition. Journal of Vegetation Science 16:223-226.

Saadre, T. 1993. Middle and Upper Ordovician discontinuity surfaces in northern Estonia (zonality based on their impregnation type). Bulletin of the Geological Survey of Estonia 3(1):33-39.

Schwarz, C. J., and A. N. Arnason. 1996. A general methodology for the analysis of capture-recapture experiments in open populations. Biometrics 52:860-873.

Sepkoski, J. J. 1988. Alpha, beta, or gamma: where does all the diversity go? Paleobiology 14:221-234.

Servais, T., and D. A. T. Harper. 2018. The Great Ordovician Biodiversification Event (GOBE): definition, concept and duration. Lethaia 51:151-164.

Servais, T., A. W. Owen, D. A. T. Harper, B. Kröger, and A. Munnecke. 2010. The Great Ordovician Biodiversification Event (GOBE): the palaeoecological dimension. Palaeogeography, Palaeoclimatology, Palaeoecology 294:99-119.

Sheehan, P. M. 1975. Brachiopod synecology in a time of crisis (Late Ordovician-Early Silurian). Paleobiology 1:205-212.

Sheehan, P. M. 2001. The late Ordovician mass extinction. Annual Review of Earth and Planetary Sciences 29:331-364.

Sheehan, P. M., and P. J. Coorough. 1990. Brachiopod zoogeography across the Ordovician-Silurian extinction event. Geological Society of London Memoir 12:181-187.

Spjeldnæs, N., and M. H. Nitecki. 1994. Baltic Ordovician lithographic limestones. Geobios 16:267-273.

Stigall, A. L. 2018. How is biodiversity produced? Examining speciation processes during the GOBE. Lethaia 51:165-172.

Stigall, A. L., J. E. Bauer, A. R. Lam, and D. F. Wright. 2017. Biotic immigration events, speciation, and the accumulation of biodiversity in the fossil record. Global and Planetary Change $148: 242-257$

Stigall, A. L., C. T. Edwards, R. L. Freeman, and C. M. Ø. Rasmussen 2019. Coordinated biotic and abiotic change during the Great Ordovician Biodiversification Event: Darriwilian assembly of early Paleozoic building blocks. Palaeogeography, Palaeoclimatology, Palaeoecology 530:249-270. 
Taylor, P. D., and C. Sendino. 2010. Latitudinal distribution of bryozoan-rich sediments in the Ordovician. Bulletin of Geosciences 85:565-572.

Taylor, P. D., and M. A. Wilson. 2003. Palaeoecology and evolution of marine hard substrate communities. Earth-Science Reviews 62:1-103.

Teller, L. 1997. The subsurface Silurian in the East European platform. In A. Urbanek and L. Teller, eds. Silurian graptolite faunas in the East European Platform: stratigraphy and evolution. Palaeontologia Polonica 56:7-21.

Torsvik, T. H., and L. R. M. Cocks. 2016. Earth history and palaeogeography. Cambridge University Press, Cambridge, 118.

Torsvik, T. H., M. A. Smethurst, J. G. Meert, R. Van der Voo, W. S. McKerrow, M. D. Brasier, B. A. Sturt, and H. J. Walderhaug. 1996. Continental break-up and collision in the Neoproterozoic and Palaeozoic - a tale of Baltica and Laurentia. Earth-Science Reviews 40:229-258.

Trotter, J. A., I. S. Williams, C. R. Barnes, C. Lécuyer, and R. S. Nicoll. 2008. Did cooling oceans trigger Ordovician biodiversification? Evidence from conodont thermometry. Science 321:550-554

Trubovitz, S., and A. L. Stigall. 2016. Synchronous diversification of Laurentian and Baltic rhynchonelliform brachiopods: implications for regional versus global triggers of the Great Ordovician Biodiversification Event. Geology 44:743-746.
Tuuling, I. 2019. The Leba Ridge-Riga-Pskov Fault Zone-a major East European Craton interior dislocation zone and its role in the early Palaeozoic development of the platform cover. Estonian Journal of Earth Sciences 68:161-189.

Tuuling, I., and T. Flodén. 2013. Silurian reefs off Saaremaa and their extension towards Gotland, central Baltic Sea. Geological Magazine 150:923-936.

Vinn, O., and M. A. Wilson. 2010. Early large borings in a hardground of Floian-Dapingian age (Early and Middle Ordovician) in northeastern Estonia (Baltica). Carnets de Géologie $4: 1-4$.

Wang, J., X. Deng, G. Wang, and Y. Li. 2012. Types and biotic successions of Ordovician reefs in China. Chinese Science Bulletin 57:1160-1168.

Webby, B. D., F. Paris, M. L. Droser, and I. G. Percival. 2004. The Great Ordovician Biodiversification Event. Columbia University Press, New York.

Whittaker, R. H. 1970. Communities and ecosystems. Macmillan, New York.

Whittaker, R. H. 1972. Evolution and measurement of species diversity. Taxon 21:213-251.

Wright, V. P., and P. M. Burgess. 2005. The carbonate factory continuum, facies mosaics and microfacies: an appraisal of some of the key concepts underpinning carbonate sedimentology. Facies 51:17-23. 